\title{
Induction of Human Intestinal and Hepatic Organic Anion Transporting Polypeptides: Where Is the Evidence for Its Relevance in Drug-Drug Interactions? ${ }^{\text {\} }$
}

\author{
A. David Rodrigues, ㄴ) Yurong Lai, Hong Shen, Manthena V.S. Varma, Andrew Rowland, \\ and Stefan Oswald
}

ADME Sciences, Medicine Design, Worldwide Research \& Development, Pfizer Inc., Groton, Connecticut (A.D.R., M.V.S.V.); Drug Metabolism Department, Gilead Sciences Inc., Foster City, California (Y.L.); Department of Metabolism \& Pharmacokinetics, BristolMyers Squibb Research \& Development, Princeton, New Jersey (H.S.); College of Medicine \& Public Health, Flinders University, Adelaide, South Australia, Australia (A.R.); and Department of Clinical Pharmacology, Center of Drug Absorption \& Transport, University Medicine of Greifswald, Greifswald, Germany (S.O.)

Received October 14, 2019; accepted December 6, 2019

\section{ABSTRACT}

Organic anion transporting polypeptides (OATPs), expressed in human liver (OATP1B1, OATP1B3, and OATP2B1) and intestine (OATP2B1), govern the pharmacokinetics (PK) of drugs (e.g., statins) and endogenous substrates (e.g., coproporphyrin I [CPI]). Their expression is known to be modulated (e.g., disease, age, and environmental factors), and they also present as the loci of clinically relevant polymorphisms and drug interactions involving inhibition. In comparison, relatively few clinical reports describe the induction of OATPs, although the effect of inducers (e.g., rifampicin [RIF], carbamazepine [CBZ]) on OATP biomarker plasma levels and statin PK has been reported. Of note, available human tissue (e.g., biopsy) protein and messenger RNA expression profiling data indicate that OATPs in gut and liver are not induced by prototypical inducers such as RIF when compared with cytochrome P450 3A4 (CYP3A4), P-glycoprotein (Pgp), multidrug resistance-associated protein 2 (MRP2), and breast cancer resistance protein (BCRP). Such results are consistent with in vitro human hepatocyte data. Therefore, the observed impact of RIF, and possibly CBZ, on statin PK $(>20 \%$ decrease in the area under the plasma concentration vs. time curve) cannot be ascribed to
OATP induction with certainty. In fact, most statins and CPI have been shown to present variously as substrates of RIF-inducible proteins such as CYP3A4, Pgp, MRP2, and BCRP. Interpretation of multidose RIF data is further complicated by its autoinduction, which likely leads to decreased inhibition of OATP. In the absence of more conclusive OATP induction data, caution is needed when modeling drug-drug interactions involving multidose inducers such as RIF.

\section{SIGNIFICANCE STATEMENT}

Presently, there is limited direct clinical evidence supporting the notion that human liver and gut organic anion transporting polypeptides (OATPs) are inducible by agents like rifampicin (RIF). Such data need to be reconciled and will pose challenges for attempting to incorporate OATP induction into physiologically based pharmacokinetics models. Although disparate sets of tissue biopsy (atorvastatin and carbamazepine) and in vitro hepatocyte (phenobarbital, chenodeoxycholate, and amprenavir) data present OATP messenger RNA induction ( $\geq 2$-fold) by agents beyond RIF, the clinical relevance of such data needs to be determined.
Introduction

Of the various solute carriers (SLCs) known to be expressed in the human liver, two organic anion transporting polypeptides (OATPs),

https://doi.org/10.1124/dmd.119.089615.

SThis article has supplemental material available at dmd.aspetjournals.org.
OATP1B1 and OATP1B3, are well characterized. A third OATP (OATP2B1) is ubiquitously expressed including the intestine and liver (Oscarson et al., 2006, 2007; Brueck et al., 2019). To a greater or lesser degree, each of the three is known to be involved in the pharmacokinetics (PK) of various drugs (e.g., statins, sartans, gliptins), endogenous compounds (e.g., coproporphyrin isomers coproporphyrin I [CPI] and CPIII, bilirubin glucuronide, and amidated bile acid glucuronides and

ABBREVIATIONS: AADAC, arylacetamide deacetylase; ABC, ATP-binding cassette; AUC, area under the plasma concentration versus time curve; BCRP, breast cancer resistance protein; BSEP (ABCG2), bile salt export pump; CAR (NR1/3), constitutive androstane receptor; CBZ, carbamazepine; CPI, coproporphyrin I; CYP2C, cytochrome P450 2C; CYP3A4, cytochrome P450 3A4; DDI, drug-drug interaction; ECCS, extended clearance classification system; $\mathrm{E}_{\max }$, maximal induction; FXR (NR1H4), farnesoid X receptor; $\mathrm{LXR} \alpha(N R 1 H 3)$, liver $\mathrm{X}$ receptor alpha; MRP2 (ABCC2), multidrug resistance-associated protein 2; OATP, organic anion transporting polypeptide; PBPK, physiologically based pharmacokinetics; Pgp (ABCB1), P-glycoprotein; PK, pharmacokinetics; PPAR, peroxisome proliferator-activated receptor; PXR (NR1/2), pregnane X-receptor; RIF, rifampicin; SLC, solute carrier. 
sulfates), and agents supporting liver function testing and imaging (de Graaf et al., 2011; Yoshikado et al., 2016; Rodrigues et al., 2018; Mori et al., 2019). Any combination of the three OATPs can also serve as the target of important drug-drug interactions (DDIs) involving inhibition (Poirier et al., 2007; Yoshida et al., 2012; Jamei et al., 2014; Vaidyanathan et al., 2016). Beyond DDIs, the expression and function of individual OATPs in human tissues can be modulated by genetic polymorphisms (e.g., loss-of-function alleles), proinflammatory mediators, viral infections, cholestatic drugs, and metabolic diseases such as nonalcoholic steatohepatitis (Le Vee et al., 2009; Gong and Kim, 2013; Clarke et al., 2014; Billington et al., 2018; Vildhede et al., 2019).

One aspect of clinical research that has received relatively little attention, when compared with drug-metabolizing enzymes (e.g., cytochrome P450 3A4 [CYP3A4]) and various ATP-binding cassette (ABC) transporters (e.g., P-glycoprotein [Pgp], multidrug resistance-associated protein 2 [MRP2, $A B C C 2]$, and breast cancer resistance protein [BCRP]), is the induction of OATPs by nuclear receptor agonists such as rifampicin (RIF) and carbamazepine (CBZ). Although regulation of OATP expression and function has been the subject of reviews (Svoboda et al., 2011; Staudinger et al., 2013; Alam et al., 2018), nuclear receptor-mediated OATP induction has been somewhat underrepresented, with some researchers studying the effect of OATP expression and genotype on the exposure of inducers and possible impact on the induction of CYP3A4. This is because inducers like RIF and hyperforin are known to be OATP substrates, which may govern their intracellular concentration and interaction with nuclear receptors such as the pregnane X receptor (PXR, NR112) (Tirona et al., 2003; Niemi et al., 2006a; Schäfer et al., 2019).

\section{Perspective}

It is accepted that RIF induces CYP3A4 and ABC transporters via the PXR, whereas CBZ (a relatively weak PXR agonist vs. RIF) manifests a somewhat different induction signature via other nuclear receptors such as the constitutive androstane receptor (CAR, NR113) (Faucette et al., 2007; Kim et al., 2010). In fact, RIF has been studied extensively as an inducer in vitro and in animals (humanized rodents and nonhuman primate), and clinical assessment has involved the use of CYP3A biomarkers (e.g., $6 \beta$-hydroxycortisol-to-cortisol urine ratio, plasma $4 \beta$ hydroxycholesterol) as well as CYP3A (e.g., midazolam) and Pgp (e.g., digoxin, dabigatran etexilate) probe drugs (Greiner et al., 1999; Rae et al., 2001; Peng et al., 2011; Li et al., 2014; Henderson et al., 2019; Tahara et al., 2019; Yamazaki et al., 2019). Because various statins are accepted clinical probes for the study of SLCO1B1 genotype-phenotype associations and inhibitory OATP DDIs, it is not surprising that there are numerous reports describing the impact of multidose RIF and CBZ on their PK (Kyrklund et al., 2003; Ucar et al., 2004; Backman et al., 2005; Chung et al., 2006; Lutz et al., 2018a,b). More recently, this has extended to the OATP biomarker CPI (Kunze et al., 2018).

At face value, one could interpret such changes in statin PK (e.g., $>20 \%$ decrease in the area under the statin plasma concentration vs. time curve [AUC]) as induction of OATP in the gut and liver and then consider such information when attempting to model multidose DDIs for new molecular entities in development (Table 1). Likewise, because plasma CPI is increasingly considered a viable OATP1B $1 / 3$ biomarker (Rodrigues et al., 2018), it is only natural to assume that decreases in its plasma concentration following RIF multiple dosing could also be reflective of OATP induction (Kunze et al., 2018). However, the predose CPI levels in plasma are not impacted by multiple doses of RIF, which indicates that OATP induction is unlikely. The decrease in maximal CPI plasma concentration following RIF dosing is more likely reflective of reduced RIF exposure, following autoinduction, that results in loss of OATP inhibition (Kunze et al., 2018).
From the standpoint of expression profiling, in vitro and human tissue biopsy data argue against clinically meaningful induction of OATPs following a probe inducer such as RIF (Fig. 1). In fact, could one make the case that documented multidose DDIs are largely driven by induction of CYP3A4 and ABC transporters in the gut and liver? At the same time, although RIF is widely studied and serves as the pharmaceutical industry's gold standard potent inducer, it is subject to autoinduction involving unidentified mechanisms (Acocella, 1978). This will further complicate the modeling of its PK and DDIs. Admittedly, there are caveats when interpreting relatively weak induction of OATPs in vitro or analyzing data from human tissues. For example, one assumes that biopsy data are reflective of the whole organ and that maximal induction $\left(\mathrm{E}_{\max }\right.$ ) ratios (e.g., CYP3A4-to-OATP1B1 or Pgp-to-OATP1B1 $\mathrm{E}_{\max }$ ratio) obtained in vitro faithfully reflect the situation in vivo.

Although we focused on human data, we do acknowledge that some investigators have explored the induction of various OATP forms expressed in animals (Rausch-Derra et al., 2001; Cheng et al., 2005; Niu et al., 2019). Recent data published by Niu et al. (2019) are particularly interesting because they deployed the cynomolgus monkey as a model to investigate the induction of OATP by RIF. The authors concluded that RIF, a known cynomolgus monkey PXR agonist and CYP3A4 inducer, does not induce cynomolgus monkey liver OATP1B1 and OATP1B3.

In the following, we discuss evidence supporting and refuting the induction of human gut and liver OATPs; clinical DDI data are described, in the context of the extended clearance classification system (ECCS), in addition to in vitro induction data and the results of human tissue expression profiling following inducer administration.

\section{Regulation of OATP Expression and Function}

Both the transcriptional and posttranslational regulation of OATP expression and function have already been reviewed extensively by others (Svoboda et al., 2011; Staudinger et al., 2013; Murray and Zhou, 2017; Alam et al., 2018). With respect to gene expression, certain OATP gene promoter regions have been characterized, transcription factor and nuclear receptor (e.g., PXR, CAR, vitamin D receptor, farnesoid X receptor [FXR, NR1H4], and liver X receptor alpha [LXR $\alpha, N R 1 H 3]$ ) binding motifs identified, and their impact on expression in cell-based assays has been studied (Jung et al., 2001, 2002; Wood et al., 2005; Meyer zu Schwabedissen and Kim, 2009; Meyer zu Schwabedissen et al., 2010; Eloranta et al., 2012).

Like many SLCs, human OATP1B1 and OATP1B3 are known to be glycosylated, undergo ubiquitination, and to be subject to kinasedependent phosphorylation. All serve to modulate their function,

TABLE 1

Reported impact of RIF and CBZ on the PK of putative OATP statin probes and biomarker CPI

\begin{tabular}{|c|c|c|c|}
\hline OATP Probe ${ }^{a}$ & Inducer $^{b}$ & $\%$ Decrease in Probe Plasma AUC & Reference \\
\hline Atorvastatin & RIF & 80 & Backman et al., 2005 \\
\hline Pravastatin & & $\sim 50 ; \sim 30$ & $\begin{array}{l}\text { Kyrklund et al., } \\
\text { 2003; Lutz et al., } \\
\text { 2018a }\end{array}$ \\
\hline Rosuvastatin & & $\sim 60$ & Lutz et al., 2018a \\
\hline Simvastatin & & $\sim 90$ & Chung et al., 2006 \\
\hline Pravastatin & CBZ & 57 & Lutz et al., 2018b \\
\hline Rosuvastatin & & 59 & Lutz et al., 2018 b \\
\hline Simvastatin & & 75 & Ucar et al., 2004 \\
\hline CPI & RIF & $\begin{array}{l}\text { No change in pre-RIF CPI } \\
\text { plasma levels (multidose vs. } \\
\text { single dose RIF) }\end{array}$ & Kunze et al., 2018 \\
\hline
\end{tabular}

${ }^{a}$ Oral statin.

${ }^{b}$ RIF $600 \mathrm{mg}$ every day for $\geq 5$ days; CBZ $300 \mathrm{mg}$ twice a day for $\geq 14$ days. 


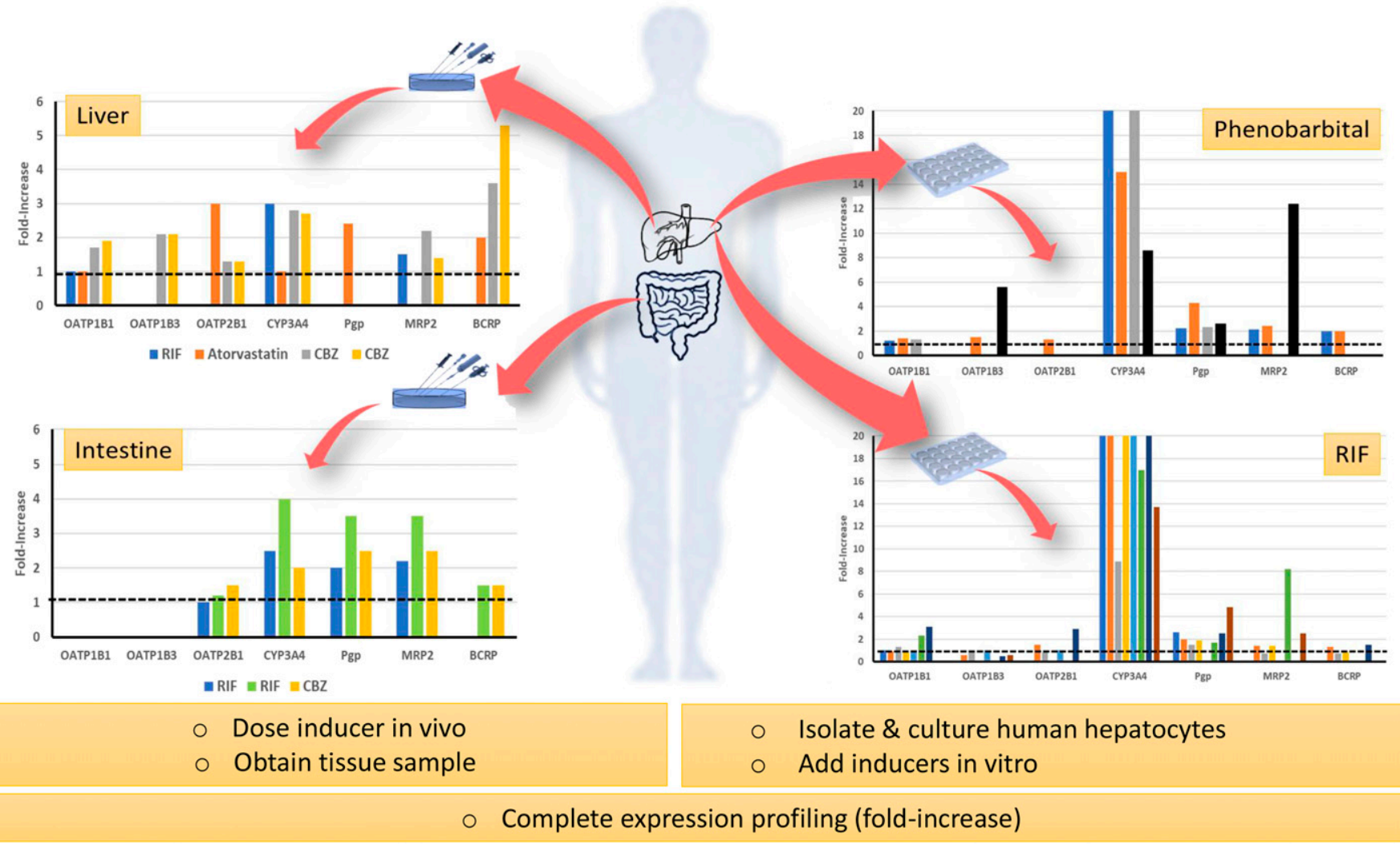

Fig. 1. Summary of available published in vitro (human hepatocytes) and ex vivo (gut and liver tissue) expression profiling data for human OATP forms, CYP3A4, and various $\mathrm{ABC}$ transporters following an inducer. Summary of data presented in Table 3 (tissue profiling) and Table 4 (cultured human hepatocytes and human liver tissue slices). Colors represent different publications (in vitro data) or inducers (tissue expression data) referenced in summary tables.

intracellular cycling, turnover, and trafficking to and from the plasma membrane (Murray and Zhou, 2017; Xu and You, 2017; Alam et al., 2018). This implies that OATP mRNA expression does not necessarily correlate with protein expression and function. Recently, Zhang and Hagenbuch (2019) have proposed that, once resident on plasma membranes, individual SLCs can form heterodimers and homodimers and form higher order structures that could be further regulated. Hypothesis testing and in vitro-in vivo extrapolations are further complicated by additional human OATPs (e.g., intestinal OATP3A1, OATP4A1, and OATP4C1) that are poorly characterized in terms of their regulation, response to inducers, and role in DDI (Oswald, 2019). Even for well-characterized OATPs, such as OATP1B1 and OATP1B3, the role of microRNAs and epigenetics (e.g., histone methylation and acetylation) in governing their expression and function must be considered (Kacevska et al., 2011, 2012; Rieger et al., 2013; Krattinger et al., 2016). Therefore, a new chemical entity could modulate basal OATP expression in a given tissue by any number of mechanisms.

Such complexity necessitates the development and careful validation of more sophisticated in vitro test systems and human-relevant animal models to support new chemical entity screening and in vitro-to-in vivo extrapolations. As described in the following, of critical importance is the consideration of OATP induction (by perpetrator) in the context of CYP3A and ABC transporter induction, as well as the role of OATP in governing the overall clearance of the victim drug and its susceptibility to such induction.

\section{Interpreting and Modeling of Clinical DDI Data and the Challenge of Using RIF as a Model Inducer}

A case can be made that the PK of statins is governed not solely by OATP but also by combinations of various $\mathrm{ABC}$ transporters expressed in the gut and liver; nearly all statins more or less present as Pgp, BCRP, and MRP2 substrates in vitro, and some present as CYP3A4 or cytochrome P450 2C (CYP2C) substrates (Jacobsen et al., 1999; Prueksaritanont et al., 1999; Yeo and Yeo, 2001; Chen et al., 2005; Huang et al., 2006; Knauer et al., 2010; Gupta et al., 2016; Shin et al., 2017; Afrouzian et al., 2018). This is particularly true for atorvastatin and rosuvastatin, whose $\mathrm{PK}$ is associated with both SLCO1B1 and BCRP ( $A B C G 2)$ genotype (Niemi, 2010). Of the statins, simvastatin is known to be extensively metabolized by CYP3A4 (Table 2), which is highly inducible by RIF (vs. OATP) in both the gut and liver (Table 3). Even so-called "selective" OATP probes like pravastatin show limited oral absorption because of $\mathrm{ABC}$ transporter-mediated efflux. For example, pravastatin is a known MRP2 substrate, which is inducible in gut and liver by RIF (Tables 2 and 3). In agreement, Shen et al. (2018) have reported that itraconazole has a minimal impact on CPI plasma levels indicative of weak OATP1B1 and OATP1B3 inhibition in vivo. However, itraconazole has been shown to increase the AUC of oral pravastatin by as much as $72 \%$ when dosed prior to the statin. Could this implicate ABC transporters? Notably, itraconazole also increases the AUC of digoxin, a widely accepted Pgp substrate (Supplemental Table 1).

It can be argued that the single dose PK of an OATP probe, such as pravastatin, is not associated with $\mathrm{ABC}$ transporter genotype (e.g., ABCG2) (Niemi, 2010). However, following an RIF induction regimen (600 mg every day, $\geq 7$ days), there is ample evidence indicating that the expression of $\mathrm{ABC}$ transporters is increased and likely leads to increased biliary and intestinal secretory clearance. Such a hypothesis, involving the induction of MRP2, has been proposed by Kyrklund et al. (2003) to explain why multidosing of RIF decreases the plasma AUC $(\sim 30 \%)$ of oral pravastatin in their study. Relatedly, Niemi et al. (2006b) reported 
TABLE 2

In vitro data presenting various OATP probes as CYP3A and $\mathrm{ABC}$ transporter substrates

\begin{tabular}{|c|c|c|c|c|c|}
\hline \multirow{2}{*}{ OATP Probe } & \multicolumn{4}{|c|}{$\begin{array}{l}\text { Is There Evidence That Probe is } \\
\text { Substrate? } ?^{a}\end{array}$} & \multirow{2}{*}{ Reference(s) } \\
\hline & CYP3A & MRP2 & BCRP & Pgp & \\
\hline CPI & N/A & Yes & No & No & Kunze et al., 2018 \\
\hline Atorvastatin & Yes & Yes & Yes & Yes & $\begin{array}{l}\text { Prueksaritanont et al., } 1999 \\
\text { Gupta et al., } 2016 \\
\text { Shin et al., } 2017 \\
\text { Knauer et al., } 2010\end{array}$ \\
\hline Pravastatin & Yes (minor) & Yes & Yes & Yes & $\begin{array}{l}\text { Jacobsen et al., } 1999 \\
\text { Afrouzian et al., } 2018\end{array}$ \\
\hline Rosuvastatin & N/A & Yes & Yes & Yes & $\begin{array}{l}\text { Huang et al., } 2006 \\
\text { Knauer et al., } 2010\end{array}$ \\
\hline Simvastatin & Yes & N/A & N/A & Yes & $\begin{array}{l}\text { Yeo and Yeo, } 2001 \\
\text { Prueksaritanont et al., } 1999 \\
\text { Chen et al., } 2005\end{array}$ \\
\hline
\end{tabular}

N/A, unable to locate reference describing the assessment of OATP probe as substrate of CYP3A and/or ABC transporter. Pgp ( $A B C B 1)$, MRP2 ( $A B C C 2)$, BCRP (ABCG2).

${ }^{a}$ Evaluated in vitro and determined to be (Yes) or not to be (No) a substrate.

a $68 \%$ decrease in pravastatin AUC in subjects carrying the $A B C C 2$ c. $1446 \mathrm{C}>\mathrm{G}$ allele, which reflects a nonsynonymous nucleotide polymorphism (threonine at position 482) on exon 10 that leads to an $\sim 2.0$ fold increase in liver MRP2 mRNA expression. The authors did not assess the impact on $A B C C 2$ genotype on intestinal MRP2 expression. As discussed in the following, such an increase in liver MRP2 expression (in the absence of OATP1B1 induction) is comparable to that reported by Marschall et al. (2005) following RIF multidosing. Overall, this implies that statins can be used as single dose OATP phenotyping tools or as probes to assess OATP inhibition in the absence of induction (i.e., following a single perpetrator dose). However, statins' use in clinical studies to investigate OATP induction per se should be questioned. The same could apply to CPI, also an MRP2 substrate, as an OATP biomarker.

\section{RIF as Inducer and Autoinducer}

Although RIF is well studied as an inducer, in many ways it remains an enigmatic drug. For example, it is an inducer of numerous drugmetabolizing enzymes beyond CYP3A4 and presents as an OATP and ABC transporter substrate in vitro (Rae et al., 2001; Tirona et al., 2003; Spears et al., 2005; Poirier et al., 2014a,b), and its inhibition of gut CYP3A4 and Pgp is a consideration when modeling and designing DDI studies involving induction (Reitman et al., 2011; Baneyx et al., 2014;
Supplemental Table 2). At the same time, although its absorptiondistribution-metabolism-excretion profile in human subjects has been documented, it is only recently that the enzymes involved in its metabolism have been identified. RIF is now known to be largely metabolized by microsomal arylacetamide deacetylase (AADAC), expressed in the gut and liver, to the 25-desacetyl RIF metabolite (Nakajima et al., 2011; Kobayashi et al., 2012). This major metabolite is recovered (with parent RIF) in urine and bile (Acocella, 1978). A second relatively minor metabolite (3-formyl RIF) is thought to be formed nonenzymatically and may itself undergo AADAC-dependent metabolism. Currently, there is no direct evidence that RIF is a CYP3A substrate, and AADAC is not inducible (at least in human hepatocytes in vitro) (Nishimura et al., 2002; N. Johnson, Pfizer, Inc., unpublished results). So why does RIF (e.g., $600 \mathrm{mg}$ every day) manifest autoinduction after multiple dosing (Acocella, 1978)?

RIF does present as an OATP1B1 (initially reported as OATP-C) and OATP1B3 (initially reported as OATP8) substrate, not as an OATP2B1 (initially reported as OATP-B) substrate (previously unpublished Pfizer data in Supplemental Table 3;Vavricka et al., 2002; Tirona et al., 2003), but we are making a case here that none of these SLCs is significantly induced in vivo. On the other hand, as described above, RIF does present as a Pgp and MRP2 substrate in vitro, and it does appear to significantly induce both $\mathrm{ABC}$ transporters in vivo (Table 3 ). Therefore, could a case be made that RIF autoinduction is the result of its induction of gut and liver Pgp and MRP2 expression, which leads to increased gut secretion and biliary clearance? Because both RIF metabolites (25-desacetyl RIF and 3-formyl RIF) are also MRP2 and Pgp substrates (Supplemental Table 3), this implies that their clearance would also be increased after multidosing of RIF. The increased recovery of parent RIF and 25desacetyl RIF in the bile of subjects dosed $600 \mathrm{mg}$ for 7 days (vs. day 1) is consistent with this hypothesis (Acocella, 1978). We noted that publications ascribed the observed autoinduction to "increased metabolism" of RIF in both the gut and liver (Acocella, 1978; Loos et al., 1987; Chirehwa et al., 2015). In hindsight, are the results of such studies reporting increased biliary and gut secretion of RIF and its metabolites via Pgp and/or MRP2? In agreement, Smythe et al. (2012) have posed a hypothesis that RIF autoinduction could be explained by PXRmediated induction of Pgp in the gut and liver.

\section{OATP Induction in the Context of PK Modeling}

Given the large number of induction studies with RIF, it is not surprising that the wealth of clinical data has spawned numerous publications describing various RIF model files to support PK and

TABLE 3

Summary of some literature reports describing OATP expression profiling of human tissues after administration of an inducer

\begin{tabular}{|c|c|c|c|c|c|c|c|c|c|}
\hline \multirow{2}{*}{ Tissue ( $N$ Subjects) } & \multirow{2}{*}{ Inducer $^{a}$} & \multicolumn{7}{|c|}{ Reported Mean Fold-Increase ${ }^{b}$} & \multirow{2}{*}{ Reference } \\
\hline & & OATP1B1 & ОАТР1B3 & OАTP2B1 & CYP3A4 & Pgp & MRP2 & BCRP & \\
\hline $\begin{array}{l}\text { Liver biopsy: inducer ( } n=6 \text { ) vs. control ( } n= \\
\text { 7) }\end{array}$ & RIF & 1.0 & NR & NR & $3.0 *$ & NR & $\begin{array}{c}1.5^{*} \\
\left(2.2^{*}\right)^{c}\end{array}$ & NR & Marschall et al., 2005 \\
\hline $\begin{array}{l}\text { Liver biopsy: inducer ( } n=10) \text { vs. control ( } n= \\
\text { 9) }\end{array}$ & Atorvastatin & 1.0 & NR & $3.0^{*}$ & 1.0 & $2.4^{*}$ & NR & $2.0 *$ & $\begin{array}{l}\text { Björkhem-Bergman et al., } \\
2013\end{array}$ \\
\hline $\begin{array}{l}\text { Liver sample: epileptics }(n=2) \text { vs. control }(n= \\
\text { 7) }\end{array}$ & CBZ & $1.7,1.9$ & $2.1,2.1$ & $1.3,1.3$ & $2.8,2.7$ & NR & $2.2,1.4$ & $\begin{array}{l}3.6 \\
5.3\end{array}$ & Oscarson et al., 2006 \\
\hline Gut (before vs. after biopsy) $(N=7)$ & RIF & NR & NR & 1.0 & $2.5^{*}$ & $2.0^{*}$ & $2.2 *$ & NR & Oscarson et al., 2007 \\
\hline Gut (before vs. after biopsy) & & & & & & & & & Brueck et al., 2019 \\
\hline$n=12$ & RIF & NR & NR & $1.2 *$ & $4.0^{*}$ & $3.5^{*}$ & $3.5^{*}$ & 1.5 & \\
\hline$n=8$ & $\mathrm{CBZ}$ & NR & NR & $1.5^{*}$ & $2.0^{*}$ & $2.5^{*}$ & $2.5^{*}$ & $1.5^{*}$ & \\
\hline
\end{tabular}

NR, not reported. Pgp (ABCB1), MRP2 (ABCC2), BCRP (ABCG2).

${ }^{a} \mathrm{RIF} 600 \mathrm{mg}$ every day for $>5$ days; atorvastatin $80 \mathrm{mg}$ every day for 30 days; CBZ $600 \mathrm{mg}$ per day for $\geq 14$ days.

${ }^{b}$ Unless otherwise indicated, data reported as fold-increase in mRNA expression; $* P<0.05$.

${ }^{c}$ Fold-increase in protein expression. 
physiologically based PK (PBPK) modeling (Reitman et al., 2011; Yamashita et al., 2013; Baneyx et al., 2014). Although numerous groups have modeled CYP3A induction, more recent PBPK models have been expanded to include induction of gut Pgp, liver CYP2C8, CYP2C9, and OATP (Asaumi et al., 2018, 2019; Hanke et al., 2018; Yamazaki et al., 2019).

In particular, the recent report by Asaumi et al. (2019) caught our attention. In this instance, the authors expanded their original RIF PBPK model (Asaumi et al., 2018) to incorporate OATP1B (OATP1B1 and OATP1B3 $)$ induction $\left(\mathrm{E}_{\max }=2.2-2.3\right)$ akin to CYP2C8 $\left(\mathrm{E}_{\max }=2.6\right)$ and assigned a concentration of inducer at half of $\mathrm{E}_{\max }\left(\mathrm{EC}_{50}\right)$ for OATP1B based on CYP3A4. It is noteworthy that additional authors claim to have similarly developed an extended PBPK model for RIF and have considered its $\operatorname{Pgp}\left(\mathrm{E}_{\max }=2.5\right), \mathrm{AADAC}\left(\mathrm{E}_{\max }=0.99\right), \mathrm{CYP} 3 \mathrm{~A} 4$ $\left(\mathrm{E}_{\max }=9.0\right)$, CYP2C8 $\left(\mathrm{E}_{\max }=3.2\right)$, OATP1B1 $\left(\mathrm{E}_{\max }=0.38\right)$, and OATP1B3 $\left(\mathrm{E}_{\max }=0.38\right)$ induction signature based on available biopsy data and in vitro data (Hanke et al., 2018; Türk et al., 2019). A major limitation is that there is no consensus regarding the best RIF $E_{\max }$ values to use as input (or for reconciling the observed DDIs) for OATP1B1 and OATP1B3 in PBPK models. Unlike OATP1B1 and OATP1B3, there is closer agreement across groups regarding the model RIF $\mathrm{E}_{\max }$ input values for Pgp, CYP3A4, and CYP2C8 (Reitman et al., 2011; Yamashita et al., 2013; Baneyx et al., 2014; Asaumi et al., 2018, 2019; Hanke et al., 2018; Yamazaki et al., 2019). On the contrary, Varma et al. (2013b, 2014) were able to describe the effect of time staggering of the RIF dose on the AUC of OATP1B, CYP3A, and CYP2C8 substrates (repaglinide and glyburide) by simply adopting CYP3A induction $\left(\mathrm{E}_{\max }\right.$ and $\left.\mathrm{EC}_{50}\right)$ and an OATP inhibition constant obtained in vitro.

\section{DDIs Involving Induction by RIF in the Context of ECCS}

Concepts involving liver clearance have evolved to include both transporter and enzymatic activity. Depending on the rates of the individual transport (active and passive transport) and metabolic processes, an "extended clearance" term may be applied to identify the rate-determining step in the overall hepatic clearance of a drug. It is generally acceptable to assume "rapid-equilibrium" conditions between blood and liver compartments for highly permeable compounds that are not substrates of an uptake transporter. In such a scenario, metabolism is typically the rate-determining step in hepatic clearance. However, when uptake via transporters such as OATP1B1 and OATP1B3 is involved, hepatic clearance can be "uptake-determined" or influenced by "transporter-enzyme interplay" (Varma et al., 2015; Kimoto et al., 2018). Therefore, OATP induction can differentially impact victim drugs manifesting rapid-equilibrium hepatic clearance, OATP uptakedetermined hepatic clearance, or OATP-enzyme interplay. However, factors such as CYP and $\mathrm{ABC}$ transporter induction in the gut and liver need to be considered also.

To identify any previously unrecognized case examples in support of OATP induction in vivo, we evaluated clinical DDIs per ECCS class following chronic treatment with RIF (Fig. 2). An extensive data set was developed with about 200 substrate drugs for which AUC ratio values (i.e., AUC without and with RIF treatment) were available. According to the ECCS framework-substrate drugs categorized based on their ionization, molecular weight, and permeability (Varma et al., 2015)—metabolism is suggested to be the primary driver of systemic clearance for high permeability basic and neutral compounds (class 2). In the case of high permeability, low molecular weight ( $\leq 400 \mathrm{Da}$ ) acidic or zwitterionic compounds (class 1A), organic anion transporter 2-enzyme interplay contributes to hepatic clearance (Kimoto et al., 2018). On the other hand, OATP1B-mediated hepatic uptake is often the primary systemic clearance mechanism for high permeability, high molecular weight $(>400 \mathrm{Da}$ ) acidic or zwitterionic compounds (class 1B).

ECCS Class 1B. Consistent with the ECCS-based assignment of the clearance mechanisms, RIF-based DDIs are predominant in class 2 with about $40 \%$ of substrate drugs showing strong interactions (AUC ratio $<0.2$ ). On the contrary, strong interactions are limited in other classes with a few exceptions, including atorvastatin and repaglinide (class 1B). Other class 1B drugs such as bosentan, glyburide, and macitentan present weak-to-moderate interactions following oral RIF treatment. Given these four drugs are predominantly metabolized by CYP3A, induction of intestinal metabolism likely contributes to the noted AUC changes. This can be substantiated in the case of atorvastatin because its oral exposure has been shown to be unaltered by intravenous itraconazole but increased $\sim 3$-fold following oral itraconazole (Kantola et al., 1998; Maeda et al., 2011). Similar conclusions can be inferred based on the mechanistic modeling and simulations for repaglinide and glyburide (Varma et al., 2013a, 2014).

ECCS Class 3A and 4. Low permeability, low molecular weight ( $\leq 400 \mathrm{Da})$ acidic or zwitterionic compounds (class 3A) and low permeability basic and neutral compounds (class 4) are primarily subjected to renal clearance. However, given the low passive permeability, these drugs are subjected to intestinal efflux via $\mathrm{ABC}$ transporters such as Pgp, BCRP, and MRP2, which may limit their oral absorption. Albeit with a small sample size, only pefloxacin showed some change in its systemic exposure following RIF treatment. Pgp-mediated efflux is thought to limit its oral absorption (fraction absorbed $\sim 60 \%$ ); thus, induction of intestinal Pgp may explain the AUC ratio of $\sim 0.57$ following RIF treatment (Griffiths et al., 1994). Similarly, weak-to-moderate RIF induction effects were also noted for class 4 drugs. Metabolically stable Pgp substrates with limited oral absorption such as aliskiren, celiprolol, dabigatran etexilate, ranitidine, and talinolol represent this class; consequently, induction of intestinal efflux further limits their oral exposure.

ECCS Class 3B. Finally, class 3B represents low permeability high molecular weight $(>400 \mathrm{Da})$ acidic or zwitterionic compounds, which are primarily cleared by OATP1B-mediated hepatic uptake and/or cleared unchanged in urine. In this instance, moderate changes in AUC are noted for OATP1B substrate drugs, including fexofenadine, rosuvastatin, and simeprevir. However, clinical evidence implies that the PK of these poorly absorbed drugs is affected by efflux inhibitors and $A B C G 2$ genotype. Although drugs such as fexofenadine and rosuvastatin involve OATP2B1-mediated intestinal absorption, the net effect of RIF treatment points toward induction of intestinal efflux transporters (Table 3).

\section{Profiling of Human Tissue after Dosing with Inducer}

\section{RIF}

It was possible to find five references describing CYP3A4, ABC transporter, and OATP human tissue expression profiling following treatment with an inducer (Fig. 1; Table 3). Four of the reports described the biopsy of study subjects before and after inducer. The work of Marschall et al. (2005) is particularly important because it is one of the few examples of liver biopsy following an inducer such as RIF. In this instance, healthy patients with gallstones (scheduled for cholestectomy) were randomized to RIF (600 mg/d for 1 week), ursodeoxycholic acid ( $1 \mathrm{~g} / \mathrm{d}$ for 3 weeks), or no medication before surgery. A liver biopsy specimen was taken to study the expression of transporters and drugmetabolizing enzymes. As expected, CYP3A4 mRNA was induced (3-fold) by RIF, which corresponded to a $247 \%$ increase in plasma biomarker levels ( $4 \beta$-hydroxycholesterol) in the same (biopsied) subjects. In contrast, ursodeoxycholic acid did not induce CYP3A4 mRNA and elicited less impact on plasma $4 \beta$-hydroxycholesterol levels 

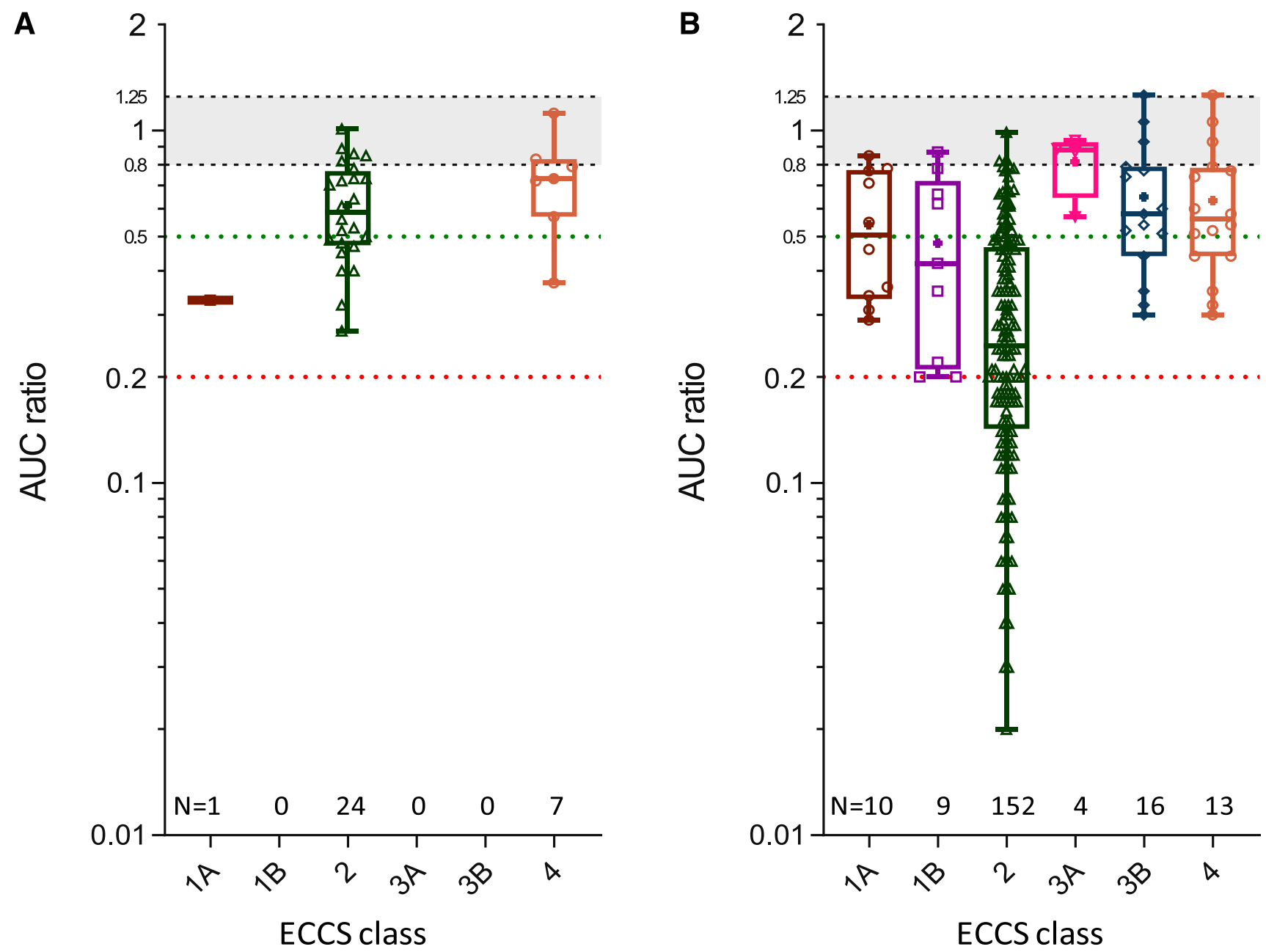

Fig. 2. Clinical DDIs per ECCS class involving a prototypic inducer such as RIF. AUC ratio of substrate drug dosed intravenously (A) and orally (B) following chronic oral RIF treatment. Open data points represent the AUC ratio of individual substrate drug; and box and whiskers depict median and upper and lower quartile with error bars representing range. Closed data points are mean values. Shaded area represents no induction, whereas horizontal green and red lines denote boundaries for no interaction (AUC ratio 0.8-1.25), as well as a weak (AUC ratio $>0.5$ ), moderate (AUC ratio 0.5-0.2), and strong (AUC ratio $<0.2$ ) induction effect. Data set was built after exhaustive and careful mining of published literature using the Metabolism and Transport Drug Interaction Database (DIDB; www.druginteractioninfo.org). ECCS class assignment was similar to that previously reported (Varma et al., 2015). For permeability classification of substrate drugs into ECCS, apparent permeability was measured across MadineDarby canine kidney cells selected for low endogenous transporter expression. Drug ionization state was assigned based on calculated pKa values using MoKa (version 2.5.4; Molecular Discovery Ltd).

(38\% increase). Of note, RIF induced MRP2 mRNA and protein expression ( 2-fold) but did not induce OATP1B1 mRNA expression. Unfortunately, the study did not evaluate the expression of Pgp, BCRP, and additional OATPs in the samples. Lack of induction of OATP1B1 by ursodeoxycholic acid is somewhat anticipated because it presents as a weak FXR agonist (vs. chenodeoxycholate) in human hepatocytes (Liu et al., 2014).

According to Oscarson et al. (2007) and Brueck et al. (2019), RIF also elicits weak induction ( $\leq 1.2$-fold) of OATP mRNA in the human gut (e.g., OATP2B1), which is somewhat surprising given the anticipated high concentrations of the inducer during first pass (Baneyx et al., 2014; Asaumi et al., 2018). Presumably, RIF interacts with PXR in the gut because the expression of CYP3A4, Pgp, and MRP2 in duodenal biopsies is induced (2.0-4.0-fold).

\section{CBZ}

To our knowledge, tissue expression profiling following oral $\mathrm{CBZ}$ is reported twice (Oscarson et al., 2006; Brueck et al., 2019); CBZ is known to interact with CAR and is a weak PXR agonist (vs. RIF). Like $\mathrm{RIF}$, tissue expression data point to $\mathrm{CBZ}$ as a relatively weak inducer of intestinal OATP2B1 when compared with CYP3A4, Pgp, MRP2, and
BCRP (Brueck et al., 2019; Table 3). However, data provided by Oscarson et al. (2006) for two epileptic subjects on CBZ are compelling. Although they used a small sample set, the authors were able to show that hepatic OATP1B1 and OATP1B3 mRNA expression was induced $\sim 2$-fold in both subjects (vs. the livers of $n=7$ control subjects); the induction was comparable to that observed for CYP3A4 and MRP2 mRNA but lower than for BCRP mRNA (3.6-, 5.3-fold).

\section{Atorvastatin}

To date, perhaps one of the most intriguing reports describing expression profiling of liver biopsy samples is by Björkhem-Bergman et al. (2013). The authors reported that OATP2B1 mRNA was statistically significantly induced (3-fold; $P<0.05$ ) in liver biopsies of subjects receiving atorvastatin ( $80 \mathrm{mg}$ for 4 weeks). In the same study, an $\sim 2$-fold induction of liver Pgp and BCRP was noted in the absence of induction of OATP1B1 and CYP3A4 mRNA. Fluvastatin $(20 \mathrm{mg} / \mathrm{d}$ for 4 weeks) was dosed in the same study but elicited a relatively minimal effect on hepatic gene expression profiles. Unfortunately, the abovedescribed biopsy data are discordant with the results of in vitro studies supporting that atorvastatin is a PXR agonist and induces CYP3A4 
mRNA ( 6-fold) in human primary hepatocytes (Hoffart et al., 2012). The exact mechanism of how atorvastatin elicits induction of hepatic OATP2B1 in vivo, without induction of OATP1B1 or CYP3A4, is not known and needs confirmation. However, it is known that the OATP2B1 gene promoter region is distinct from that of OATP1B1 and OATP1B3, which explains its broader tissue expression profile and possibly its differentiated induction signature (Maeda et al., 2006).

\section{In Vitro Data}

We also turned our attention to various publications describing studies with cryopreserved human primary hepatocytes in culture (coculture or sandwich) and precision-cut human liver tissue slices rather than hepatic (e.g., HepG2, HepaRG, and Huh7) or intestinal (e.g., Caco-2, LS180, T84 and LS174T) cell lines. Unfortunately, reports of RIF incubation with primary human enterocytes, as well as precision-cut human intestinal slices, have largely focused on CYP3A4 and ABC transporters (van de Kerkhof et al., 2008; Li et al., 2018).

\section{Plated Human Primary Hepatocytes}

Examples of reports describing studies with human primary hepatocytes in culture are shown in Table 4 and focus as much as possible on papers reporting multiple OATPs, RIF dose response, single RIF concentrations that were well above the reported $\mathrm{EC}_{50}$ for PXRmediated CYP3A4 induction in vitro, and direct comparisons with CYP3A4 and ABC transporters in the same experiment. Some investigators were able to leverage proteomics, which is important when considering pre- versus posttranslation changes after addition of inducer to hepatocytes (Schaefer et al., 2012; Alam et al., 2018).

RIF and Phenobarbital. As summarized in Fig. 1 and Table 4, it is evident that RIF and other compounds like phenobarbital are relatively weak inducers of OATP mRNA (vs. CYP3A4). The reports of Jigorel et al. (2006), Sahi et al. (2006), Chen et al. (2011), Badolo et al. (2015), Han et al. (2017), Moscovitz et al. (2018), and Niu et al. (2019) more or less indicate that OATP induction is only a fraction of that observed for CYP3A4; i.e., the relative $\mathrm{E}_{\max }$ for OATP versus CYP3A4 ( $\mathrm{E}_{\max }$ ratio) at $\sim 10 \mu \mathrm{M}$ RIF is $\leq 0.1$. The report of Moscovitz et al. (2018) is noteworthy because the authors studied RIF over a concentration range $(0.1-10 \mu \mathrm{M})$ and defined a "maximal observed induction" metric for OATP1B1 (3.1), OATP1B3 (0.5), OATP2B1 (2.9), and CYP3A4 (75). However, these data are based on mRNA expression, which does not necessarily translate to protein and function. Therefore, our attention also focused on the work of Schaefer et al. (2012) because the investigators deployed tandem liquid chromatography-mass spectrometry methods to quantitate transporter protein abundance in human hepatocytes after 48 hours with RIF $(25 \mu \mathrm{M})$. In this instance, induction of CYP3A4 protein was evident (8.9-fold) when compared with OATP1B1, OATP1B3, OATP2B1, and the ABC transporters (Pgp, $\mathrm{MRP} 2$, and BCRP) that were quantitated ( $\leq 1.5$-fold induction).

Amprenavir. To date, Liu et al. (2012) have reported the highest magnitude induction of OATP1B1 mRNA in human hepatocytes (7-fold). This was achieved with the human immunodeficiency virus 1 protease inhibitor amprenavir, a known PXR agonist (Helsley et al., 2013). The same authors noted that this was accompanied by a 1.8-, 15-, 2.5-, and 1.5-fold increase in OATP1B3, CYP3A4, Pgp, and MRP2 mRNA expression, respectively. In the same study, RIF induced OATP1B1 mRNA expression 2.5-fold (Table 4). To our knowledge, there are no clinical reports describing tissue biopsy profiling after multiple doses of amprenavir. Therefore, such in vitro data also need to be corroborated.

CBZ. As described above, Oscarson et al. (2006) reported $\sim 2$-fold induction of OATP1B1 and OATP1B3 mRNA expression in the livers of two epileptic subjects receiving CBZ. Unfortunately, we are aware of only one report by Badolo et al. (2015) that described the lack of OATP1B1 mRNA induction in plated human hepatocytes after the addition of $\mathrm{CBZ}$ at a low concentration $(5 \mu \mathrm{M})$. In the same study, the authors also showed that induction of cytochromes P450, BCRP, MRP2, and Pgp mRNA expression by CBZ was weak ( $\leq 2.0$-fold). Because $\mathrm{CBZ}$ at high concentrations $(>10 \mu \mathrm{M})$ is known to present as an inducer of CYP3A4 (Luo et al., 2002; Sugiyama et al., 2016), additional in vitro studies are warranted to further explore CBZ as an OATP inducer.

\section{Precision-Cut Human Liver Tissue Slices}

We felt it important to include the publication of Olinga et al. (2008) because the investigators used freshly prepared precision-cut human liver tissue slices and incubated with RIF ( $10 \mu \mathrm{M}, 16$ hours) and a low concentration of phenobarbital (50 $\mu \mathrm{M}, 24$ hours). As expected, RIF induced CYP3A4 (14-fold), Pgp (4.8-fold), and MRP2 (2.5-fold) mRNA expression (Table 4). No induction of OATP1B3 (reported as OATP8) mRNA expression was observed (OATP1B1 and OATP2B1 not reported). On the other hand, the same authors did observe robust induction of OATP1B3 mRNA expression (5.6-fold) with phenobarbital, a CAR ligand, which accompanied mRNA increases for CYP3A4 (8.6fold), MRP2 (12.4-fold), and Pgp (2.6-fold). Such marked induction of OATP1B3 has not been replicated by other investigators using cultured human hepatocytes incubated with higher phenobarbital concentrations $(1 \mathrm{mM})$ (Schaefer et al., 2012). Unfortunately, we were unable to locate human liver biopsy expression data for phenobarbital-dosed subjects, and so the results reported by Olinga et al. (2008) cannot be corroborated.

\section{Studies with FXR Agonists}

For the sake of completeness, we also wanted to consider additional publications describing in vitro studies with agonists for additional nuclear receptors beyond PXR and CAR. A summary of our findings for a well-characterized FXR agonist (chenodeoxycholic acid) is tabulated (Table 5). Three reports described studies with conventional plated human primary hepatocytes (Meyer zu Schwabedissen et al., 2010; Liu et al., 2014; Krattinger et al., 2016), and one leveraged precision-cut human liver slices (Jung et al., 2007). In all cases, induction ( $\geq 3$-fold) of bile salt export pump (BSEP, $A B C B 11$ ) mRNA was evident and was indicative of FXR engagement. Although induction of OATP1B1 mRNA varied considerably across the studies (0.6- to 4-fold), the induction of OATP1B3 mRNA was more evident and in three of the four studies was reported as $\geq 3.5$-fold (Table 5).

To date, chenodeoxycholic acid is the most robust and consistent in vitro inducer of any OATP (OATP1B3) reported. Unfortunately, we are not aware of any studies describing tissue biopsy expression profiling following chenodeoxycholate dosing, as was done for ursodeoxycholate (Marschall et al., 2005). Alternatively, we looked to a semisynthetic FXR agonist like obeticholic acid ( $6 \alpha$-ethyl-chenodeoxycholic acid), which similarly elicits robust induction ( $>5$-fold) of BSEP and small heterodimer partner mRNA expression in sandwich-cultured human hepatocytes (Zhang et al., 2017). But unlike chenodeoxycholic acid, clinical data are available for multidose obeticholic acid showing that it has a minimal effect on the AUC of an orally dosed BCRP or OATP probe drug (rosuvastatin) (Edwards et al., 2017). Consistent with such clinical data, Ijssennagger et al. (2016) have reported that obeticholic acid $(1 \mu \mathrm{M})$ elicits a relatively modest effect on OATP1B1 and OATP1B3 mRNA expression (vs. induction of $\mathrm{ABCB} 11 \mathrm{mRNA}$ ) in precision-cut human liver slices.

\section{Studies with Peroxisome Proliferator-Activated Receptor and LXR $\alpha$ Agonists}

To our knowledge, Meyer zu Schwabedissen et al. (2010) are the only group to describe OATP induction in vitro with an $\mathrm{LXR} \alpha$ agonist such 
TABLE 4

Summary of literature reports describing OATP expression profiling after addition of inducer to cultured human primary hepatocytes and human liver tissue slices in vitro

\begin{tabular}{|c|c|c|c|c|c|c|c|c|}
\hline \multirow{2}{*}{ Inducer $^{a}$} & \multicolumn{7}{|c|}{ Reported Mean Fold-Change (vs. Control) ${ }^{b}$} & \multirow{2}{*}{ Reference } \\
\hline & OATP1B1 & OATP1B3 & OATP2B1 & CYP3A4 & Pgp & MRP2 & BCRP & \\
\hline RIF & 1.0 & NR & NR & 23 & 2.6 & NR & NR & Chen et al., 2011 \\
\hline Phenobarbital & 1.3 & NR & NR & 21 & 2.3 & NR & NR & \\
\hline $\mathrm{RIF}^{c}$ & 1.3 & 0.9 & 0.8 & 8.9 & 1.5 & 0.7 & 0.7 & Schaefer et al., 2012 \\
\hline Phenobarbital $^{c}$ & 1.4 & 1.5 & 1.3 & 15 & 4.3 & 2.4 & 2.0 & \\
\hline RIF & 0.8 & NR & NR & 40 & 1.9 & 1.4 & 0.8 & Badolo et al., 2015 \\
\hline Phenobarbital & 1.2 & NR & NR & 45 & 2.2 & 2.1 & 2.0 & \\
\hline RIF & $\leq 1.0$ & $\leq 1.0$ & $\leq 1.0$ & $\geq 20$ & NR & NR & NR & Han et al., 2017 \\
\hline RIF & 2.3 & NR & NR & 17 & 1.7 & 8.2 & NR & Sahi et al., 2006 \\
\hline $\mathrm{RIF}^{d}$ & 3.1 & 0.5 & 2.9 & 75 & 2.5 & NR & 1.5 & Moscovitz et al., 2018 \\
\hline $\mathrm{RIF}^{e}$ & NR & 0.6 & NR & 13.7 & 4.8 & 2.5 & NR & Olinga et al., 2008 \\
\hline Phenobarbital $^{e}$ & NR & 5.6 & NR & 8.6 & 2.6 & 12.4 & NR & \\
\hline RIF & 0.9 & 0.6 & 1.5 & 59 & 2.0 & 1.4 & 1.3 & Niu et al., 2019 \\
\hline RIF & 2.4 & $\leq 1.0$ & $\leq 1.0$ & 37 & 2.9 & 2.5 & 2.7 & Jigorel et al., 2006 \\
\hline Phenobarbital $^{f}$ & NR & $\leq 1.0$ & $\leq 1.0$ & NR & 4.4 & 3.8 & 3.7 & \\
\hline RIF & 2.5 & 1.0 & NR & 5.5 & 2.5 & 1.5 & NR & Liu et al., 2012 \\
\hline Amprenavir ${ }^{g}$ & 7.0 & 1.8 & NR & 15 & 2.5 & 1.5 & NR & \\
\hline
\end{tabular}

NR, not reported. Pgp ( $A B C B 1)$, MRP2 (ABCC2), BCRP (ABCG2).

${ }^{a}$ Unless otherwise indicated, data represent cultured human primary hepatocytes exposed to RIF ( $\left.\geq 10 \mu \mathrm{M}\right)$ for $\geq 24 \mathrm{~h}$; phenobarbital ( $1 \mathrm{mM}$ ) for $48 \mathrm{~h}$.

${ }^{b}$ Unless otherwise indicated, data reported as fold-increase in mRNA expression.

${ }^{c}$ Fold-increase in protein expression.

${ }^{d}$ Maximal observed fold-induction (over a concentration range of $0.1-10 \mu \mathrm{M}$ ).

${ }^{e}$ Human liver tissue slices incubated with RIF $(10 \mu \mathrm{M}$ for $16 \mathrm{~h})$ or phenobarbital $(50 \mu \mathrm{M}$ for $24 \mathrm{~h})$.

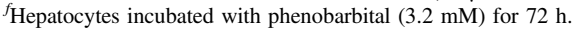

${ }^{g}$ Final concentration of amprenavir was $10 \mu \mathrm{M}$.

as TO-901317. The authors incubated TO-901317 with plated human hepatocytes and showed that OATP1B1 mRNA is induced $(\sim 2.5$-fold $)$ with a more muted effect ( $\sim 1.2$-fold induction) on OATP1B3 mRNA expression. Likewise, Rogue et al. $(2010,2011)$ have assessed the mRNA expression signatures of primary human hepatocytes after the addition of peroxisome proliferator-activated receptor (PPAR) $\gamma$ (NR1C3) agonists (e.g., troglitazone and rosiglitazone) and dual PPAR $\alpha / \gamma$ (NR1C1/NR1C3) agonists (e.g., muraglitazar). Test compounds were assessed at relatively high concentrations (up to $40-300 \mu \mathrm{M}$ ), and none was shown to induced OATP1B1 or OATP1B3 mRNA expression. In fact, suppression of OATP1B3 mRNA expression was noted. Such results are consistent with those of Chen et al. (2011), who similarly reported no induction of OATP1B1 mRNA in freshly prepared cocultures of human primary hepatocytes incubated with WY14643 (100 $\mu \mathrm{M}, \operatorname{PPAR} \alpha$ agonist). In all cases, investigators described robust induction ( $\geq 6$-fold) of known PPAR-regulated genes such as adipose differentiation-related protein.

\section{Assessing OATP Induction: An Evolving Toolkit}

As summarized in Table 6, various approaches could be jointly used to investigate the induction of OATPs in vitro and in vivo, support in vitro-to-in vivo extrapolations, and enable modeling and simulation exercises. However, many of the described tools need to be adapted to support the assessment of OATP induction by test compounds and still require validation prior to being widely accepted.

\section{In Vitro}

Given the examples described in Tables 4 and 5, induction studies with human primary hepatocytes or tissue slices are advisable as primary in vitro screens. If OATP induction is evident (e.g., $>2$-fold increase in mRNA and protein) it should be compared with CYP3A4 and various $\mathrm{ABC}$ transporters and relative $\mathrm{E}_{\max }$ values generated. Because new chemical entities may present unique induction signatures in hepatocytes, versus standard inducers such as RIF, CBZ, and phenytoin, additional studies with nuclear receptor transactivation assays (e.g., PXR, CAR, FXR, LXR $\alpha$, vitamin $\mathrm{D}$ receptor) may have to be considered to rationalize the gene induction signatures observed in primary calls (Meyer zu Schwabedissen et al., 2010; Howe et al., 2011; Eloranta et al., 2012). In vitro induction studies could be extended to include burgeoning novel plate-based and chip-based microphysiological systems (e.g., liver organoids and liver-on-a-chip) that might better support the assessment of OATP expression and function and their modulation by test compounds (Ishida, 2018). To date, however, we are not aware of any reports describing the impact of test compounds on OATP expression in such systems.

TABLE 5

Chenodeoxycholic acid as inducer of OATP1B1, OATP1B3, MRP2, and BSEP in vitro

\begin{tabular}{lccccc}
\hline \multirow{2}{*}{ Human Hepatocyte Preparation } & \multicolumn{2}{c}{ Reported Fold-Increase in mRNA Expression (vs. Control) } & Reference \\
\cline { 2 - 5 } & OATP1B1 & OATP1B3 & MRP2 & BSEP & Meyer Zu Schwabedissen et al., 2010 \\
\hline Cultured cells $^{a}$ & $\sim 4.0$ & $\sim 3.5$ & NR & $\sim 3.5$ & Liu et al., 2014 \\
Cultured cells $^{b}$ & NR & $\sim 6.0$ & $\sim 2.0$ & $\sim 9.0$ & Krattinger et al., 2016 \\
Cultured cells $^{c}$ & 0.7 & 1.5 & NR & 4.6 & Jung et al., 2007 \\
Liver slices $^{d}$ & 0.6 & 4.5 & NR & 3.0 & \\
\hline
\end{tabular}

NR, not reported.

${ }^{a}$ Chenodeoxycholate conc. and incubation not specified by the authors.

${ }^{b}$ Chenodeoxycholate $30 \mu \mathrm{M}(48 \mathrm{~h})$.

${ }^{c}$ Chenodeoxycholate $50 \mu \mathrm{M}(48 \mathrm{~h})$.

${ }^{d}$ Chenodeoxycholate $10 \mu \mathrm{M}(24 \mathrm{~h})$. 
TABLE 6

Summary of tools that could be available to assess the induction of human OATPs

\begin{tabular}{|c|c|c|}
\hline Approach & Comment & References (Where Available) \\
\hline $\begin{array}{l}\text { 1. In vitro nuclear hormone receptor } \\
\text { transactivation assays (assumes that } \\
\text { receptor agonism drives OATP induction) }\end{array}$ & $\begin{array}{l}\text { Important to assess if compound is PXR, } \\
\text { CAR, LXR, FXR, or vitamin D receptor } \\
\text { agonist }\end{array}$ & $\begin{array}{l}\text { Meyer Zu Schwabedissen et al., 2010; } \\
\text { Howe et al., 2011; Eloranta et al., } 2012\end{array}$ \\
\hline $\begin{array}{l}\text { 2. Primary human cells in vitro (plated } \\
\text { hepatocytes, tissue slices); OATP protein } \\
\text { and mRNA expression assessment vs. } \\
\text { CYP and ABC transporter expression }\end{array}$ & $\begin{array}{l}\text { Reports available describing assessment of } \\
\text { OATP induction vs. CYP and ABC } \\
\text { transporters }\end{array}$ & Described in Tables 4 and 5 \\
\hline $\begin{array}{l}\text { 3. Primary human cells in vitro (three- } \\
\text { dimensional organoids, tissue-on-a-chip); } \\
\text { OATP protein and mRNA expression } \\
\text { assessment vs. CYP and ABC transporter } \\
\text { expression }\end{array}$ & Needs validation for OATP induction & $\begin{array}{l}\text { To date, no references describing OATP } \\
\text { induction in organoids or tissue-on-a- } \\
\text { chip }\end{array}$ \\
\hline $\begin{array}{l}\text { 4. Humanized rodents (e.g., humanized } \\
\text { OATP, humanized liver); OATP protein } \\
\text { and mRNA tissue expression assessment } \\
\text { vs. CYP and ABC transporter expression }\end{array}$ & $\begin{array}{l}\text { Needs validation for various PXR, CAR, FXR, } \\
\text { and LXR agonists }\end{array}$ & $\begin{array}{l}\text { To date, no references describing OATP } \\
\text { induction in the tissues of humanized } \\
\text { rodents }\end{array}$ \\
\hline 5. Nonhuman primate (primary hepatocytes) & $\begin{array}{l}\text { Report available for PXR agonist (RIF) } \\
\text { describing assessment of cynomolgus } \\
\text { monkey OATP induction vs. CYP and ABC } \\
\text { transporters }\end{array}$ & Niu et al., 2019 \\
\hline $\begin{array}{l}\text { 6. Nonhuman primate tissue biopsy (e.g., gut } \\
\text { and liver) following administration of } \\
\text { inducer for greater than } 7 \text { days }\end{array}$ & $\begin{array}{l}\text { Targeted and nontargeted transcriptomic and } \\
\text { proteome analysis; compare OATP vs. } \\
\text { CYP3A and ABC transporters }\end{array}$ & $\begin{array}{l}\text { To date, no references describing OATP } \\
\text { tissue expression profiling following } \\
\text { inducer }\end{array}$ \\
\hline $\begin{array}{l}\text { 7. Tissue biopsy (intestine and/or liver) of } \\
\text { human subjects following administration } \\
\text { of inducer }\end{array}$ & $\begin{array}{l}\text { Reports available describing assessment of } \\
\text { OATP induction vs. CYP3A and ABC } \\
\text { transporters }\end{array}$ & Described in Table 3 \\
\hline $\begin{array}{l}\text { 8. Support of clinical induction study using } \\
\text { a liquid biopsy approach (plasma-derived } \\
\text { tissue exosomes or circulating human } \\
\text { lymphocytes) }\end{array}$ & $\begin{array}{l}\text { One report describing the use of circulating } \\
\text { human lymphocytes, but liquid biopsy } \\
\text { approaches need validation }\end{array}$ & Yang et al., 2019 \\
\hline $\begin{array}{l}\text { 9. Use of a selective OATP biomarker or } \\
\text { probe drug that is minimally influenced by } \\
\text { CYP and/or ABC transporter induction } \\
\text { (e.g., gut and/or liver MRP2, Pgp, or } \\
\text { BCRP) }\end{array}$ & $\begin{array}{l}\text { Selective gut and/or liver OATP probe has not } \\
\text { been identified, characterized, and } \\
\text { validated; CPI might be an option, provided } \\
\text { test compound does not inhibit OATP and } \\
\text { present autoinduction like RIF }\end{array}$ & $\begin{array}{l}\text { To date, there are no references describing } \\
\text { selective OATP biomarkers or drug } \\
\text { probes suitable for multidose OATP } \\
\text { induction studies }\end{array}$ \\
\hline
\end{tabular}

\section{Animal Models}

Beyond in vitro assays, various attempts have been made to assess in vivo induction in extensively humanized mice or chimeric mice with humanized livers (Kakuni et al., 2013; Henderson et al., 2019). But in such instances, reports have largely focused on the induction of CYP3A4 by classic inducers such as RIF, and no data are available for OATP1B1 and OATP1B3. Evidently, there is a need to study the induction of human OATPs in such models.

In recent years, the cynomolgus monkey has increasingly been used as a model to investigate PXR-mediated induction of CYP3A by agents such as RIF. This is because monkey PXR is highly homologous to the human ortholog (96\%) and cynomolgus monkey CYP3A is inducible by RIF both in vitro and in vivo (Kim et al., 2010; Li et al., 2014; Tahara et al., 2019). In fact, the RIF dose response curves for CYP3A4 induction in plated cynomolgus monkey and human primary hepatocytes are comparable (Kim et al., 2010). With this mind, it is not surprising that Niu et al. (2019) turned to the cynomolgus monkey as a model to study OATP induction by RIF. The authors described the dosing of cynomolgus monkeys with RIF for 7 days $(18 \mathrm{mg} / \mathrm{kg}$ ), using a protocol known to induce monkey CYP3A, and reported an $\sim 2$-fold increase in antipyrine clearance (cytochrome P450 mediated) with no impact on pitavastatin, CPI, and CPIII plasma exposure. RIF similarly increases antipyrine clearance in human subjects (Bennett et al., 1982). The lack of OATP induction was confirmed after the addition of RIF (10 $\mu \mathrm{M}, 72$ hour) to sandwich-cultured cynomolgus monkey hepatocytes; CYP3A4, MRP2, Pgp, BCRP, OATP1B1, and OATP1B3 mRNA was induced 58-, 2.2-, 1.4-, 1.4-, 0.9-, and 1.3-fold, respectively. Of note, no attempt was made by the authors to isolate liver or gut tissue, before and after the dosing of the monkeys with RIF, to support OATP, CYP3A4, and $\mathrm{ABC}$ transporter expression profiling.

Consistent with the report of Niu et al. (2019), mRNA expressing profiling of cynomolgus monkey liver tissue after $\sim 9$ days of oral RIF (100 mg/kg), CBZ ( $80 \mathrm{mg} / \mathrm{kg})$, or phenytoin $(30 \mathrm{mg} / \mathrm{kg}$ ) presents robust induction of various CYP3A forms (up to 19-fold) with no statistically significant changes in SLCO1B1 and SLCO1B3 expression (W. Hu and S. Arat, Pfizer Inc., unpublished results). Beyond a PXR agonist such as RIF, however, it is not known if the cynomolgus monkey is a suitable in vivo model to assess OATP induction via other mechanisms or nuclear receptors such as $\mathrm{CAR}, \mathrm{LXR} \alpha, \mathrm{FXR}$, or vitamin $\mathrm{D}$ receptor.

\section{Liquid Biopsy Approaches to Facilitate Tissue Expression Profiling}

As described above, the use of clinical drug probes and biomarkers to study OATP induction has its limitations, and human tissue biopsy expression profiling is likely the most direct approach to differentiate OATP induction versus CYP3A4 and ABC transporters. But because conventional tissue biopsy methods are not routine, researchers may wish to turn their attention to less invasive strategies such as plasma exosome-based liquid biopsy (Rodrigues and Rowland, 2019). For example, Rowland et al. (2019) recently described the assessment of CYP3A4 activity, protein, and mRNA induction using exosome preparations derived from the plasma of subjects who had received RIF (300 mg daily) for 7 days. With validation, a similar approach could be applied to the assessment of OATP protein and mRNA expression. Alternatively, the expression of OATPs in circulating human lymphocytes has been described, and attempts have been made to deploy them as liver and gut tissue surrogates; Yang et al. (2019) reported an $\sim 2$-fold increase in 
OATP1B1 and BCRP mRNA expression in the circulating lymphocytes of subjects who had consumed an herbal medicine ( $2.5 \mathrm{~g}$ tanjin per day) for 7 days. Both the maximal plasma concentration (27\%) and AUC ( 20\%) of rosuvastatin were decreased in the same subjects. How such induction in circulating lymphocytes relates to OATP expression in tissue is presently not known. Most importantly, such results need to be confirmed, as others have failed to detect OATP1B1 mRNA expression in various human T-cell lines and blood mononuclear cells (Janneh et al., 2008).

\section{Selective OATP Drug Probes and Biomarkers}

From the standpoint of an OATP induction toolkit, perhaps the most challenging is the discovery and validation of clinical probe drugs and biomarkers that are highly selective for target gut and liver OATPs. In the absence of biopsy data, assessing and deconvoluting gut (e.g., OATP2B1) versus liver (e.g., OATP1B1 and OATP1B3) OATP induction will be difficult. Such a scenario is further complicated by coinduction of CYP3A4 and $\mathrm{ABC}$ transporters in both organs. As discussed above, changes in statin and OATP biomarker (CPI) PK cannot be necessarily ascribed to OATP induction in the absence of ABC transporter induction. To date, however, we are aware of only one study describing multidose RIF on plasma CPI levels (Kunze et al., 2018). Because CPI is selective for OATP1B1 and OATP1B3 (vs. OATP2B1) and limited to MRP2 as substrate (Bednarczyk and Boiselle, 2016; Kunze et al., 2018; Table 2), additional clinical studies evaluating its utility as an OATP induction trait measure are warranted. This is especially true for inducers that do not inhibit OATP or manifest autoinduction like RIF.

\section{Concluding Remarks}

Human OATPs (OATP1B1, OATP1B3, and OATP2B1) are important SLCs, and their modulation by inhibitory drugs has been shown to be of clinical relevance for many substrate drugs. When compared with such DDIs, however, there is less definitive clinical data describing their induction. Despite such limitations, it is possible to conclude that available literature describes only weak induction of OATPs (mostly mRNA data) following treatment with a gold standard potent PXR activator (RIF $600 \mathrm{mg}$ once daily $\geq 7$ days). By extension, it is assumed that the reported changes in individual statin PK (and OATP biomarker CPI plasma profiles), following multiple doses of RIF, can be ascribed to the induction of CYP3A4 and ABC transporters in gut and liver, as we all as RIF autoinduction.

Beyond RIF, disparate sets of data do provide some evidence that human OATP forms are inducible ( $>2$-fold). As described above, OATP induction has been described for compounds such as atorvastatin (3-fold OATP2B1 mRNA induction in human liver biopsy samples), phenobarbital ( $\sim 6$-fold OATP1B3 mRNA induction in human liver slices), CBZ ( 2-fold induction of OATP1B1 and OATP1B3 mRNA in livers of two epileptic subjects), chenodeoxycholate ( $\sim 2$ - to 6-fold OATP1B3 mRNA induction in plated human hepatocytes), TO-901317 ( $\sim 2.5$-fold induction of OATP1B1 in plated human hepatocytes), and amprenavir ( $\sim 7$-fold OATP1B1 induction in plated human hepatocytes). Although such results need to be corroborated, it appears that studies focused on the induction of gut and liver OATP1B1, OATP1B3, and OATP2B1 by agents other than RIF are warranted. Also, other OATP forms such as OATP1A2, OATP3A1, OATP4A1, and OATP4C1 should be considered (Eloranta et al., 2012; Oswald, 2019).

Evidently, the regulation of OATP expression and function is complex, and continuous vigilance will be needed, especially when attempting to model DDIs with new chemical entities that are OATP inducers in vitro or present as OATP substrates that may themselves become victims of induction. In reality, such data need to be balanced against a new chemical entity's cytochrome P450 and ABC transporter substrate, induction, and inhibition signature. With substantial clinical evidence supporting Pgp induction for well-known CYP3A inducers (Lutz et al., 2018a,b; Supplemental Table 4), the US Food and Drug Administration has suggested leveraging information from CYP3A induction studies to rationalize the need for conducting additional clinical studies to evaluate the Pgp induction potential of an investigational drug using a known Pgp probe substrate (https://www.fda.gov/ media/82734/download). On the basis of the exhaustive clinical and preclinical data reviewed here, however, a clear need to evaluate OATP induction potential in drug development does not emerge at this time. Most importantly, the apparent lack of OATP induction by drugs such as RIF in vivo should be diligently considered when developing extended PBPK models encompassing OATP induction-inhibition signatures in addition to the associated interaction mechanisms involving CYP3A4, CYP2C9, CYP2C8, MRP2, Pgp, and BCRP.

\section{Acknowledgments}

The authors would like to thank Mark West, Sarah Lazzaro, and Soraya Eatemadpour (Pfizer Inc.) for providing the transporter data presented in Supplemental Table 3. Drs. Wenyue Hu and Seda Arat (Pfizer Inc.) are also acknowledged for a personal communication regarding their unpublished cynomolgus monkey liver tissue mRNA expression profiling data following inducer administration. Nathaniel Johnson (Pfizer Inc.) is also acknowledged for a personal communication regarding the lack of induction of AADAC mRNA in human hepatocytes after the addition of RIF.

\section{Authorship Contributions}

Wrote or contributed to the writing of the manuscript: Rodrigues, Lai, Shen, Varma, Rowland, Oswald.

\section{References}

Acocella G (1978) Clinical pharmacokinetics of rifampicin. Clin Pharmacokinet 3:108-127.

Afrouzian M, Al-Lahham R, Patrikeeva S, Xu M, Fokina V, Fischer WG, Abdel-Rahman SZ, Costantine M, Ahmed MS, and Nanovskaya T (2018) Role of the efflux transporters BCRP and MRP1 in human placental bio-disposition of pravastatin. Biochem Pharmacol 156:467-478.

Alam K, Crowe A, Wang X, Zhang P, Ding K, Li L, and Yue W (2018) Regulation of organic anion transporting polypeptides (OATP) 1B1- and OATP1B3-mediated transport: an updated review in the context of OATP-mediated drug-drug interactions. Int J Mol Sci 19:E855.

Asaumi R, Menzel K, Lee W, Nunoya KI, Imawaka H, Kusuhara H, and Sugiyama Y (2019) Expanded physiologically-based pharmacokinetic model of rifampicin for predicting interactions with drugs and an endogenous biomarker via complex mechanisms including organic anion transporting polypeptide 1B induction. CPT Pharmacometrics Syst Pharmacol 8:845-857.

Asaumi R, Toshimoto K, Tobe Y, Hashizume K, Nunoya KI, Imawaka H, Lee W, and Sugiyama Y (2018) Comprehensive PBPK model of rifampicin for quantitative prediction of complex drugdrug interactions: CYP3A/2C9 induction and OATP inhibition effects. CPT Pharmacometrics Syst Pharmacol 7:186-196.

Backman JT, Luurila H, Neuvonen M, and Neuvonen PJ (2005) Rifampin markedly decreases and gemfibrozil increases the plasma concentrations of atorvastatin and its metabolites. Clin Pharmacol Ther 78:154-167.

Badolo L, Jensen B, Säll C, Norinder U, Kallunki P, and Montanari D (2015) Evaluation of 309 molecules as inducers of CYP3A4, CYP2B6, CYP1A2, OATP1B1, OCT1, MDR1, MRP2, MRP3 and BCRP in cryopreserved human hepatocytes in sandwich culture. Xenobiotica 45: 177-187.

Baneyx G, Parrott N, Meille C, Iliadis A, and Lavé T (2014) Physiologically based pharmacokinetic modeling of CYP3A4 induction by rifampicin in human: influence of time between substrate and inducer administration. Eur J Pharm Sci 56:1-15.

Bednarczyk D and Boiselle C (2016) Organic anion transporting polypeptide (OATP)-mediated transport of coproporphyrins I and III. Xenobiotica 46:457-466.

Bennett PN, John VA, and Whitmarsh VB (1982) Effect of rifampicin on metoprolol and antipyrine kinetics. Br J Clin Pharmacol 13:387-391.

Billington S, Ray AS, Salphati L, Xiao G, Chu X, Humphreys WG, Liao M, Lee CA, Mathias A, Hop CECA, et al. (2018) Transporter expression in noncancerous and cancerous liver tissue from donors with hepatocellular carcinoma and chronic hepatitis C infection quantified by LC-MS/MS proteomics. Drug Metab Dispos 46:189-196.

Björkhem-Bergman L, Bergström H, Johansson M, Parini P, Eriksson M, Rane A, and Ekström L (2013) Atorvastatin treatment induces uptake and efflux transporters in human liver. Drug Metab Dispos 41:1610-1615.

Brueck S, Bruckmueller H, Wegner D, Busch D, Martin P, Oswald S, Cascorbi I, and Siegmund W (2019) Transcriptional and post-transcriptional regulation of duodenal P-glycoprotein and MRP2 in healthy human subjects after chronic treatment with rifampin and carbamazepine. Mol Pharm 16:3823-3830.

Chen C, Han YH, Yang Z, and Rodrigues AD (2011) Effect of interferon- $\alpha 2 b$ on the expression of various drug-metabolizing enzymes and transporters in co-cultures of freshly prepared human primary hepatocytes. Xenobiotica 41:476-485.

Chen C, Mireles RJ, Campbell SD, Lin J, Mills JB, Xu JJ, and Smolarek TA (2005) Differential interaction of 3-hydroxy-3-methylglutaryl-coa reductase inhibitors with $\mathrm{ABCB} 1, \mathrm{ABCC} 2$, and OATP1B1. Drug Metab Dispos 33:537-546. 
Cheng X, Maher J, Dieter MZ, and Klaassen CD (2005) Regulation of mouse organic aniontransporting polypeptides (Oatps) in liver by prototypical microsomal enzyme inducers that activate distinct transcription factor pathways. Drug Metab Dispos 33:1276-1282.

Chirehwa MT, Rustomjee R, Mthiyane T, Onyebujoh P, Smith P, McIlleron H, and Denti P (2015) Model-based evaluation of higher doses of rifampin using a semimechanistic model incorporating autoinduction and saturation of hepatic extraction. Antimicrob Agents Chemother $\mathbf{6 0}$ : $487-494$.

Chung E, Nafziger AN, Kazierad DJ, and Bertino JS Jr (2006) Comparison of midazolam and simvastatin as cytochrome P450 3A probes. Clin Pharmacol Ther 79:350-361.

Clarke JD, Hardwick RN, Lake AD, Lickteig AJ, Goedken MJ, Klaassen CD, and Cherrington NJ (2014) Synergistic interaction between genetics and disease on pravastatin disposition. J Hepatol 61:139-147.

de Graaf W, Häusler S, Heger M, van Ginhoven TM, van Cappellen G, Bennink RJ, Kullak-Ublick GA, Hesselmann R, van Gulik TM, and Stieger B (2011) Transporters involved in the hepatic uptake of (99m)Tc-mebrofenin and indocyanine green. J Hepatol 54:738-745.

Edwards JE, Eliot L, Parkinson A, Karan S, and MacConell L (2017) Assessment of pharmacokinetic interactions between obeticholic acid and caffeine, midazolam, warfarin, dextromethorphan, omeprazole, rosuvastatin, and digoxin in phase 1 studies in healthy subjects. $A d v$ Ther 34:2120-2138.

Eloranta JJ, Hiller C, Jüttner M, and Kullak-Ublick GA (2012) The SLCO1A2 gene, encoding human organic anion-transporting polypeptide $1 \mathrm{~A} 2$, is transactivated by the vitamin D receptor. Mol Pharmacol 82:37-46.

Faucette SR, Zhang TC, Moore R, Sueyoshi T, Omiecinski CJ, LeCluyse EL, Negishi M, and Wang $H$ (2007) Relative activation of human pregnane $X$ receptor versus constitutive androstane receptor defines distinct classes of CYP2B6 and CYP3A4 inducers. J Pharmacol Exp Ther 320:72-80.

Gong IY and Kim RB (2013) Impact of genetic variation in OATP transporters to drug disposition and response. Drug Metab Pharmacokinet 28:4-18.

Greiner B, Eichelbaum M, Fritz P, Kreichgauer HP, von Richter O, Zundler J, and Kroemer HK (1999) The role of intestinal P-glycoprotein in the interaction of digoxin and rifampin. J Clin Invest 104:147-153.

Griffiths NM, Hirst BH, and Simmons NL (1994) Active intestinal secretion of the fluoroquinolone antibacterials ciprofloxacin, norfloxacin and pefloxacin; a common secretory pathway? J Pharmacol Exp Ther 269:496-502.

Gupta A, Harris JJ, Lin J, Bulgarelli JP, Birmingham BK, and Grimm SW (2016) Fusidic acid inhibits hepatic transporters and metabolic enzymes: potential cause of clinical drug-drug interaction observed with statin coadministration. Antimicrob Agents Chemother 60 $5986-5994$

Han KM, Ahn SY, Seo H, Yun J, Cha HJ, Shin JS, Kim YH, Kim H, Park HK, and Lee YM (2017) Bosentan and rifampin interactions modulate influx transporter and cytochrome P450 expression and activities in primary human hepatocytes. Biomol Ther (Seoul) 25:288-295.

Hanke N, Frechen S, Moj D, Britz H, Eissing T, Wendl T, and Lehr T (2018) PBPK models for CYP3A4 and P-gp DDI prediction: a modeling network of rifampicin, itraconazole, clarithromycin, midazolam, alfentanil, and digoxin. CPT Pharmacometrics Syst Pharmacol 7 : 647-659.

Helsley RN, Sui Y, Ai N, Park SH, Welsh WJ, and Zhou C (2013) Pregnane X receptor mediates dyslipidemia induced by the HIV protease inhibitor amprenavir in mice. Mol Pharmacol $\mathbf{8 3}$ $1190-1199$.

Henderson CJ, Kapelyukh Y, Scheer N, Rode A, McLaren AW, MacLeod AK, Lin D, Wright J, Stanley LA, and Wolf CR (2019) An extensively humanized mouse model to predict pathways of drug disposition and drug/drug interactions, and to facilitate design of clinical trials. Drug Metab Dispos 47:601-615.

Hoffart E, Ghebreghiorghis L, Nussler AK, Thasler WE, Weiss TS, Schwab M, and Burk O (2012) Effects of atorvastatin metabolites on induction of drug-metabolizing enzymes and membrane transporters through human pregnane X receptor. Br J Pharmacol 165:1595-1608.

Howe K, Sanat F, Thumser AE, Coleman T, and Plant N (2011) The statin class of HMG-CoA reductase inhibitors demonstrate differential activation of the nuclear receptors PXR, CAR and FXR, as well as their downstream target genes. Xenobiotica 41:519-529.

Huang L, Wang Y, and Grimm S (2006) ATP-dependent transport of rosuvastatin in membrane vesicles expressing breast cancer resistance protein. Drug Metab Dispos 34:738-742.

Ijssennagger N, Janssen AWF, Milona A, Ramos Pittol JM, Hollman DAA, Mokry M, Betzel B, Berends FJ, Janssen IM, van Mil SWC, et al. (2016) Gene expression profiling in human precision cut liver slices in response to the FXR agonist obeticholic acid. J Hepatol 64: $1158-1166$.

Ishida S (2018) Organs-on-a-chip: current applications and consideration points for in vitro ADMETox studies. Drug Metab Pharmacokinet 33:49-54.

Jacobsen W, Kirchner G, Hallensleben K, Mancinelli L, Deters M, Hackbarth I, Benet LZ, Sewing KF, and Christians U (1999) Comparison of cytochrome P-450-dependent metabolism and drug interactions of the 3-hydroxy-3-methylglutaryl-CoA reductase inhibitors lovastatin and pravastatin in the liver. Drug Metab Dispos 27:173-179.

Jamei M, Bajot F, Neuhoff S, Barter Z, Yang J, Rostami-Hodjegan A, and Rowland-Yeo K (2014) A mechanistic framework for in vitro-in vivo extrapolation of liver membrane transporters: prediction of drug-drug interaction between rosuvastatin and cyclosporine. Clin Pharmacokine 53:73-87.

Janneh O, Hartkoorn RC, Jones E, Owen A, Ward SA, Davey R, Back DJ, and Khoo SH (2008) Cultured CD4T cells and primary human lymphocytes express hOATPs: intracellular accumulation of saquinavir and lopinavir. Br J Pharmacol 155:875-883.

Jigorel E, Le Vee M, Boursier-Neyret C, Parmentier Y, and Fardel O (2006) Differential regulation of sinusoidal and canalicular hepatic drug transporter expression by xenobiotics activating drugsensing receptors in primary human hepatocytes. Drug Metab Dispos 34:1756-1763.

Jung D, Elferink MG, Stellaard F, and Groothuis GM (2007) Analysis of bile acid-induced regulation of FXR target genes in human liver slices. Liver Int 27:137-144.

Jung D, Hagenbuch B, Gresh L, Pontoglio M, Meier PJ, and Kullak-Ublick GA (2001) Characterization of the human OATP-C (SLC21A6) gene promoter and regulation of liver-specific OATP genes by hepatocyte nuclear factor 1 alpha. J Biol Chem 276:37206-37214.

Jung D, Podvinec M, Meyer UA, Mangelsdorf DJ, Fried M, Meier PJ, and Kullak-Ublick GA (2002) Human organic anion transporting polypeptide 8 promoter is transactivated by the farnesoid X receptor/bile acid receptor. Gastroenterology 122:1954-1966.

Kacevska M, Ivanov M, and Ingelman-Sundberg M (2011) Perspectives on epigenetics and its relevance to adverse drug reactions. Clin Pharmacol Ther 89:902-907.
Kacevska M, Ivanov M, and Ingelman-Sundberg M (2012) Epigenetic-dependent regulation of drug transport and metabolism: an update. Pharmacogenomics 13:1373-1385.

Kakuni M, Yamasaki C, Tachibana A, Yoshizane Y, Ishida Y, and Tateno C (2013) Chimeric mice with humanized livers: a unique tool for in vivo and in vitro enzyme induction studies. Int $\mathrm{J}$ Mol Sci 15:58-74.

Kantola T, Kivistö KT, and Neuvonen PJ (1998) Effect of itraconazole on the pharmacokinetics of atorvastatin. Clin Pharmacol Ther 64:58-65.

Kim S, Dinchuk JE, Anthony MN, Orcutt T, Zoeckler ME, Sauer MB, Mosure KW, Vuppugalla R, Grace JE Jr, Simmermacher J, et al. (2010) Evaluation of cynomolgus monkey pregnane X receptor, primary hepatocyte, and in vivo pharmacokinetic changes in predicting human CYP3A4 induction. Drug Metab Dispos 38:16-24.

Kimoto E, Mathialagan S, Tylaska L, Niosi M, Lin J, Carlo AA, Tess DA, and Varma MVS (2018) Organic anion transporter 2-mediated hepatic uptake contributes to the clearance of high-permeability-low-molecular-weight acid and zwitterion drugs: evaluation using 25 drugs $J$ Pharmacol Exp Ther 367:322-334.

Knauer MJ, Urquhart BL, Meyer zu Schwabedissen HE, Schwarz UI, Lemke CJ, Leake BF, Kim RB, and Tirona RG (2010) Human skeletal muscle drug transporters determine local exposure and toxicity of statins. Circ Res 106:297-306.

Kobayashi Y, Fukami T, Nakajima A, Watanabe A, Nakajima M, and Yokoi T (2012) Species differences in tissue distribution and enzyme activities of arylacetamide deacetylase in human, rat, and mouse. Drug Metab Dispos 40:671-679.

Krattinger R, Boström A, Lee SML, Thasler WE, Schiöth HB, Kullak-Ublick GA, and Mwinyi J (2016) Chenodeoxycholic acid significantly impacts the expression of miRNAs and genes involved in lipid, bile acid and drug metabolism in human hepatocytes. Life Sci 156:47-56.

Kunze A, Ediage EN, Dillen L, Monshouwer M, and Snoeys J (2018) Clinical investigation of coproporphyrins as sensitive biomarkers to predict mild to strong OATP1B-mediated drug-drug interactions. Clin Pharmacokinet 57:1559-1570.

Kyrklund C, Backman JT, Neuvonen M, and Neuvonen PJ (2003) Gemfibrozil increases plasma pravastatin concentrations and reduces pravastatin renal clearance. Clin Pharmacol Ther 73: $538-544$.

Le Vee M, Lecureur V, Stieger B, and Fardel O (2009) Regulation of drug transporter expression in human hepatocytes exposed to the proinflammatory cytokines tumor necrosis factor-alpha or interleukin-6. Drug Metab Dispos 37:685-693.

Li AP, Alam N, Amaral K, Ho MD, Loretz C, Mitchell W, and Yang Q (2018) Cryopreserved human intestinal mucosal epithelium: a novel in vitro experimental system for the evaluation of enteric drug metabolism, cytochrome P450 induction, and enterotoxicity. Drug Metab Dispos 46: $1562-1571$

Li K, Zhao S, Zhang L, Wu X, Shu P, Wang Y, Feng H, Gu Z, and Han Hsu H (2014) 4ßHydroxycholesterol as an endogenous biomarker of CYP3A activity in cynomolgus monkeys. Drug Metab Dispos 42:839-843.

Liu J, Lu H, Lu YF, Lei X, Cui JY, Ellis E, Strom SC, and Klaassen CD (2014) Potency of individual bile acids to regulate bile acid synthesis and transport genes in primary human hepatocyte cultures. Toxicol Sci 141:538-546.

Liu L, Mugundu GM, Kirby BJ, Samineni D, Desai PB, and Unadkat JD (2012) Quantification of human hepatocyte cytochrome P450 enzymes and transporters induced by HIV protease inhibitors using newly validated LC-MS/MS cocktail assays and RT-PCR. Biopharm Drug Dispos 33:207-217.

Loos U, Musch E, Jensen JC, Schwabe HK, and Eichelbaum M (1987) Influence of the enzyme induction by rifampicin on its presystemic metabolism. Pharmacol Ther 33:201-204.

Luo G, Cunningham M, Kim S, Burn T, Lin J, Sinz M, Hamilton G, Rizzo C, Jolley S, Gilbert D, et al. (2002) CYP3A4 induction by drugs: correlation between a pregnane $\mathrm{X}$ receptor reporter gene assay and CYP3A4 expression in human hepatocytes. Drug Metab Dispos 30:795-804.

Lutz JD, Kirby BJ, Wang L, Song Q, Ling J, Massetto B, Worth A, Kearney BP, and Mathias A (2018a) Cytochrome P450 3A induction predicts P-glycoprotein induction; part 1: establishing induction relationships using ascending dose rifampin. Clin Pharmacol Ther 104:1182-1190.

Lutz JD, Kirby BJ, Wang L, Song Q, Ling J, Massetto B, Worth A, Kearney BP, and Mathias A (2018b) Cytochrome P450 3A induction predicts P-glycoprotein induction; part 2: prediction of decreased substrate exposure after rifabutin or carbamazepine. Clin Pharmacol Ther 104: $1191-1198$.

Maeda K, Ikeda Y, Fujita T, Yoshida K, Azuma Y, Haruyama Y, Yamane N, Kumagai Y, and Sugiyama $Y$ (2011) Identification of the rate-determining process in the hepatic clearance of atorvastatin in a clinical cassette microdosing study. Clin Pharmacol Ther 90:575-581.

Maeda T, Hirayama M, Higashi R, Sato M, and Tamai I (2006) Characterization of human OATP2B1 (SLCO2B1) gene promoter regulation. Pharm Res 23:513-520.

Marschall HU, Wagner M, Zollner G, Fickert P, Diczfalusy U, Gumhold J, Silbert D, Fuchsbichler A, Benthin L, Grundström R, et al. (2005) Complementary stimulation of hepatobiliary transport and detoxification systems by rifampicin and ursodeoxycholic acid in humans. Gastroenterology 129:476-485

Meyer zu Schwabedissen HE, Böttcher K, Chaudhry A, Kroemer HK, Schuetz EG, and Kim RB (2010) Liver $X$ receptor $\alpha$ and farnesoid $X$ receptor are major transcriptional regulators of OATP1B1. Hepatology 52:1797-1807.

Meyer zu Schwabedissen HE and Kim RB (2009) Hepatic OATP1B transporters and nuclear receptors PXR and CAR: interplay, regulation of drug disposition genes, and single nucleotide polymorphisms. Mol Pharm 6:1644-1661.

Mori D, Kimoto E, Rago B, Kondo Y, King-Ahmad A, Ramanathan R, Wood LS, Johnson JG, Le VH, Vourvahis M, et al. (2019) Dose-dependent inhibition of OATP1B by rifampicin in healthy volunteers: comprehensive evaluation of candidate biomarkers and OATP1B probe drugs. Clin Pharmacol Ther DOI: 10.1002/cpt.1695 [published ahead of print]

Moscovitz JE, Kalgutkar AS, Nulick K, Johnson N, Lin Z, Goosen TC and Weng Y (2018) Establishing transcriptional signatures to differentiate PXR-, CAR-, and AhR-mediated regulation of drug metabolism and transport genes in cryopreserved human hepatocytes. J Pharmaco Exp Ther 365:262-271.

Murray M and Zhou F (2017) Trafficking and other regulatory mechanisms for organic anion transporting polypeptides and organic anion transporters that modulate cellular drug and xenobiotic influx and that are dysregulated in disease. Br J Pharmacol 174:1908-1924.

Nakajima A, Fukami T, Kobayashi Y, Watanabe A, Nakajima M, and Yokoi T (2011) Human arylacetamide deacetylase is responsible for deacetylation of rifamycins: rifampicin, rifabutin, and rifapentine. Biochem Pharmacol 82:1747-1756.

Niemi M (2010) Transporter pharmacogenetics and statin toxicity. Clin Pharmacol Ther 87: $130-133$. 
Niemi M, Arnold KA, Backman JT, Pasanen MK, Gödtel-Armbrust U, Wojnowski L, Zanger UM, Neuvonen PJ, Eichelbaum M, Kivistö KT, et al. (2006b) Association of genetic polymorphism in $\mathrm{ABCC} 2$ with hepatic multidrug resistance-associated protein 2 expression and pravastatin pharmacokinetics. Pharmacogenet Genomics 16:801-808.

Niemi M, Kivistö KT, Diczfalusy U, Bodin K, Bertilsson L, Fromm MF, and Eichelbaum M (2006a) Effect of SLCO1B1 polymorphism on induction of CYP3A4 by rifampicin. Pharmacogenet Genomics 16:565-568.

Nishimura M, Yoshitsugu H, Naito S, and Hiraoka I (2002) Evaluation of gene induction of drugmetabolizing enzymes and transporters in primary culture of human hepatocytes using highsensitivity real-time reverse transcription PCR. Yakugaku Zasshi 122:339-361.

Niu C, Wang Y, Zhao X, Tep S, Murakami E, Subramanian R, Smith B, and Lai Y (2019) Organic anion-transporting polypeptide genes are not induced by the pregnane $\mathrm{X}$ receptor activator rifampin: studies in hepatocytes in vitro and in monkeys in vivo. Drug Metab Dispos 47:1433-1442.

Olinga P, Elferink MG, Draaisma AL, Merema MT, Castell JV, Pérez G, and Groothuis GM (2008) Coordinated induction of drug transporters and phase I and II metabolism in human liver slices. Eur J Pharm Sci 33:380-389.

Oscarson M, Burk O, Winter S, Schwab M, Wolbold R, Dippon J, Eichelbaum M, and Meyer UA (2007) Effects of rifampicin on global gene expression in human small intestine. Pharmacogene Genomics 17:907-918.

Oscarson M, Zanger UM, Rifki OF, Klein K, Eichelbaum M, and Meyer UA (2006) Transcriptional profiling of genes induced in the livers of patients treated with carbamazepine. Clin Pharmacol Ther 80:440-456.

Oswald S (2019) Organic anion transporting polypeptide (OATP) transporter expression, localization and function in the human intestine. Pharmacol Ther 195:39-53.

Peng CC, Templeton I, Thummel KE, Davis C, Kunze KL, and Isoherranen N (2011) Evaluation of $6 \beta$-hydroxycortisol, $6 \beta$-hydroxycortisone, and a combination of the two as endogenous probes for inhibition of CYP3A4 in vivo. Clin Pharmacol Ther 89:888-895.

Poirier A, Cascais AC, Bader U, Portmann R, Brun ME, Walter I, Hillebrecht A, Ullah M, and Funk C (2014a) Calibration of in vitro multidrug resistance protein 1 substrate and inhibition assays as a basis to support the prediction of clinically relevant interactions in vivo. Drug Metab Dispos 42:1411-1422.

Poirier A, Funk C, Lavé T, and Noé J (2007) New strategies to address drug-drug interactions involving OATPs. Curr Opin Drug Discov Devel 10:74-83.

Poirier A, Portmann R, Cascais AC, Bader U, Walter I, Ullah M, and Funk C (2014b) The need for human breast cancer resistance protein substrate and inhibition evaluation in drug discovery and development: why, when, and how? Drug Metab Dispos 42:1466-1477.

Prueksaritanont T, Ma B, Tang C, Meng Y, Assang C, Lu P, Reider PJ, Lin JH, and Baillie TA (1999) Metabolic interactions between mibefradil and HMG-CoA reductase inhibitors: an in vitro investigation with human liver preparations. Br J Clin Pharmacol 47:291-298.

Rae JM, Johnson MD, Lippman ME, and Flockhart DA (2001) Rifampin is a selective, pleiotropic inducer of drug metabolism genes in human hepatocytes: studies with cDNA and oligonucleotide expression arrays. J Pharmacol Exp Ther 299:849-857.

Rausch-Derra LC, Hartley DP, Meier PJ, and Klaassen CD (2001) Differential effects of microsomal enzyme-inducing chemicals on the hepatic expression of rat organic anion transporters, OATP1 and OATP2. Hepatology 33:1469-1478.

Reitman ML, Chu X, Cai X, Yabut J, Venkatasubramanian R, Zajic S, Stone JA, Ding Y, Witter R, Gibson C, et al. (2011) Rifampin's acute inhibitory and chronic inductive drug interactions: experimental and model-based approaches to drug-drug interaction trial design. Clin Pharmacol Ther 89:234-242.

Rieger JK, Klein K, Winter S, and Zanger UM (2013) Expression variability of absorption, distribution, metabolism, excretion-related microRNAs in human liver: influence of nongenetic factors and association with gene expression. Drug Metab Dispos 41:1752-1762.

Rodrigues AD, Taskar KS, Kusuhara H, and Sugiyama Y (2018) Endogenous probes for drug transporters: balancing vision with reality. Clin Pharmacol Ther 103:434-448.

Rodrigues D and Rowland A (2019) From endogenous compounds as biomarkers to plasmaderived nanovesicles as liquid biopsy; has the golden age of translational pharmacokineticsabsorption, distribution, metabolism, excretion-drug-drug interaction science finally arrived? Clin Pharmacol Ther 105:1407-1420.

Rogue A, Spire C, Brun M, Claude N, and Guillouzo A (2010) Gene expression changes induced by PPAR gamma agonists in animal and human liver. PPAR Res 2010:325183.

Rogue A, Lambert C, Jossé R, Antherieu S, Spire C, Claude N, and Guillouzo A (2011) Comparative gene expression profiles induced by PPAR $\gamma$ and PPAR $\alpha / \gamma$ agonists in human hepatocytes. PLoS One 6:e18816.

Rowland A, Ruanglertboon W, van Dyk M, Wijayakumara D, Wood LS, Meech R, Mackenzie PI, Rodrigues AD, Marshall JC, and Sorich MJ (2019) Plasma extracellular nanovesicle (exosome)derived biomarkers for drug metabolism pathways: a novel approach to characterize variability in drug exposure. Br J Clin Pharmacol 85:216-226.

Sahi J, Sinz MW, Campbell S, Mireles R, Zheng X, Rose KA, Raeissi S, Hashim MF, Ye Y, de Morais SM, et al. (2006) Metabolism and transporter-mediated drug-drug interactions of the endothelin-A receptor antagonist CI-1034. Chem Biol Interact 159:156-168.

Schäfer AM, Potterat O, Seibert I, Fertig O, and Meyer Zu Schwabedissen HE (2019) Hyperforininduced activation of the pregnane $\mathrm{X}$ receptor is influenced by the organic anion-transporting polypeptide 2B1. Mol Pharmacol 95:313-323.

Schaefer O, Ohtsuki S, Kawakami H, Inoue T, Liehner S, Saito A, Sakamoto A, Ishiguro N, Matsumaru T, Terasaki T, et al. (2012) Absolute quantification and differential expression of drug transporters, cytochrome P450 enzymes, and UDP-glucuronosyltransferases in cultured primary human hepatocytes. Drug Metab Dispos 40:93-103.

Shen H, Christopher L, Lai Y, Gong J, Kandoussi H, Garonzik S, Perera V, Garimella T, and Humphreys WG (2018) Further studies to support the use of coproporphyrin I and III as novel clinical biomarkers for evaluating the potential for organic anion transporting polypeptide 1B1 and OATP1B3 inhibition. Drug Metab Dispos 46:1075-1082.

Shin E, Shin N, Oh JH, and Lee YJ (2017) High-dose metformin may increase the concentration of atorvastatin in the liver by inhibition of multidrug resistance-associated protein 2. J Pharm Sci 106:961-967.

Smythe W, Khandelwal A, Merle C, Rustomjee R, Gninafon M, Bocar Lo M, Sow OB, Olliaro PL, Lienhardt C, Horton J, et al. (2012) A semimechanistic pharmacokinetic-enzyme turnover model for rifampin autoinduction in adult tuberculosis patients. Antimicrob Agents Chemother 56:2091-2098.
Spears KJ, Ross J, Stenhouse A, Ward CJ, Goh LB, Wolf CR, Morgan P, Ayrton A, and Friedberg TH (2005) Directional trans-epithelial transport of organic anions in porcine LLC-PK1 cells that co-express human OATP1B1 (OATP-C) and MRP2. Biochem Pharmacol 69:415-423.

Staudinger JL, Woody S, Sun M, and Cui W (2013) Nuclear-receptor-mediated regulation of drugand bile-acid-transporter proteins in gut and liver. Drug Metab Rev 45:48-59.

Sugiyama I, Murayama N, Kuroki A, Kota J, Iwano S, Yamazaki H, and Hirota T (2016) Evaluation of cytochrome P450 inductions by anti-epileptic drug oxcarbazepine, 10 hydroxyoxcarbazepine, and carbamazepine using human hepatocytes and HepaRG cells. Xenobiotica 46:765-774.

Svoboda M, Riha J, Wlcek K, Jaeger W, and Thalhammer T (2011) Organic anion transporting polypeptides (OATPs): regulation of expression and function. Curr Drug Metab 12:139-153.

Tahara H, Watanabe M, and Hasegawa M (2019) A comparative study for detecting CYP3A induction by CYP3A probe drugs and endogenous markers in cynomolgus monkeys. Biopharm Drug Dispos 40:81-93.

Tirona RG, Leake BF, Wolkoff AW, and Kim RB (2003) Human organic anion transporting polypeptide-C (SLC21A6) is a major determinant of rifampin-mediated pregnane $\mathrm{X}$ receptor activation. J Pharmacol Exp Ther 304:223-228.

Türk D, Hanke N, Wolf S, Frechen S, Eissing T, Wendl T, Schwab M, and Lehr T (2019) Physiologically based pharmacokinetic models for prediction of complex CYP2C8 and OATP1B1 (SLCO1B1) drug-drug-gene interactions: a modeling network of gemfibrozil, repaglinide, pioglitazone, rifampicin, clarithromycin and itraconazole. Clin Pharmacokinet 58: 1595-1607.

Ucar M, Neuvonen M, Luurila H, Dahlqvist R, Neuvonen PJ, and Mjörndal T (2004) Carbamazepine markedly reduces serum concentrations of simvastatin and simvastatin acid. Eur J Clin Pharmacol 59:879-882.

Vaidyanathan J, Yoshida K, Arya V, and Zhang L (2016) Comparing various in vitro prediction criteria to assess the potential of a new molecular entity to inhibit organic anion transporting polypeptide 1B1. J Clin Pharmacol 56 (Suppl 7):S59-S72.

van de Kerkhof EG, de Graaf IA, Ungell AL, and Groothuis GM (2008) Induction of metabolism and transport in human intestine: validation of precision-cut slices as a tool to study induction of drug metabolism in human intestine in vitro. Drug Metab Dispos 36:604-613.

Varma MV, Lai Y, Kimoto E, Goosen TC, El-Kattan AF, and Kumar V (2013a) Mechanistic modeling to predict the transporter- and enzyme-mediated drug-drug interactions of repaglinide. Pharm Res 30:1188-1199.

Varma MV, Lin J, Bi YA, Rotter CJ, Fahmi OA, Lam JL, El-Kattan AF, Goosen TC, and Lai Y (2013b) Quantitative prediction of repaglinide-rifampicin complex drug interactions using dynamic and static mechanistic models: delineating differential CYP3A4 induction and OATP1B1 inhibition potential of rifampicin. Drug Metab Dispos 41:966-974.

Varma MV, Scialis RJ, Lin J, Bi Y-A, Rotter CJ, Goosen TC, and Yang X (2014) Mechanismbased pharmacokinetic modeling to evaluate transporter-enzyme interplay in drug interactions and pharmacogenetics of glyburide. AAPS $J$ 16:736-748.

Varma MV, Steyn SJ, Allerton C, and El-Kattan AF (2015) Predicting clearance mechanism in drug discovery: extended clearance classification system (ECCS). Pharm Res 32: $3785-3802$

Vavricka SR, Van Montfoort J, Ha HR, Meier PJ, and Fattinger K (2002) Interactions of rifamycin SV and rifampicin with organic anion uptake systems of human liver. Hepatology 36:164-172.

Vildhede A, Kimoto E, Pelis RM, Rodrigues AD, and Varma MVS (2019) Quantitative proteomics and mechanistic modeling of transporter-mediated disposition in non-alcoholic fatty liver disease. Clin Pharmacol Ther DOI: 10.1002/cpt.1699 [published ahead of print].

Wood M, Ananthanarayanan M, Jones B, Wooton-Kee R, Hoffman T, Suchy FJ, and Vore M (2005) Hormonal regulation of hepatic organic anion transporting polypeptides. Mol Pharmacol 68:218-225.

Xu D and You G (2017) Loops and layers of post-translational modifications of drug transporters. Adv Drug Deliv Rev 116:37-44.

Yamazaki S, Costales C, Lazzaro S, Eatemadpour S, Kimoto E, and Varma MV (2019) Physiologically-based pharmacokinetic modeling approach to predict rifampin-mediated intestinal P-glycoprotein induction. CPT Pharmacometrics Syst Pharmacol 8:634-642.

Yamashita F, Sasa Y, Yoshida S, Hisaka A, Asai Y, Kitano H, Hashida M, and Suzuki H (2013) Modeling of rifampicin-induced CYP3A4 activation dynamics for the prediction of clinical drugdrug interactions from in vitro data. PLoS One 8:e70330.

Yang J, Hasegawa J, Endo Y, Iitsuka K, Yamamoto M, and Matsuda A (2019) Pharmacokinetic drug interaction between rosuvastatin and tanjin in healthy volunteers and rats. Yonago Acta Med 62:77-84.

Yeo KR and Yeo WW (2001) Inhibitory effects of verapamil and diltiazem on simvastatin metabolism in human liver microsomes. Br J Clin Pharmacol 51:461-470.

Yoshida K, Maeda K, and Sugiyama Y (2012) Transporter-mediated drug--drug interactions involving OATP substrates: predictions based on in vitro inhibition studies. Clin Pharmacol The 91:1053-1064.

Yoshikado T, Yoshida K, Kotani N, Nakada T, Asaumi R, Toshimoto K, Maeda K, Kusuhara H, and Sugiyama Y (2016) Quantitative analyses of hepatic OATP-mediated interactions between statins and inhibitors using PBPK modeling with a parameter optimization method. Clin Pharmacol Ther 100:513-523.

Zhang Y and Hagenbuch B (2019) Protein-protein interactions of drug uptake transporters that are important for liver and kidney. Biochem Pharmacol 168:384-391.

Zhang Y, Jackson JP, St Claire RL III, Freeman K, Brouwer KR, and Edwards JE (2017) Obeticholic acid, a selective farnesoid $\mathrm{X}$ receptor agonist, regulates bile acid homeostasis in sandwich-cultured human hepatocytes. Pharmacol Res Perspect 5:e0329.

Address correspondence to: Dr. A. David Rodrigues, ADME Sciences, Medicine Design, Worldwide Research \& Development, Pfizer Inc., Eastern Point Road, Bldg 220/002/2565, Mail Stop 8220-2439, Pfizer Inc., Groton, CT 06340. E-mail: a.david. rodrigues@pfizer.com 